\title{
Review of Heterogeneous Catalysts for Catalytically Upgrading Vegetable Oils into Hydrocarbon Biofuels
}

\author{
Xianhui Zhao ${ }^{1,2}$, Lin Wei ${ }^{1}{ }^{1 *}$, Shouyun Cheng ${ }^{1}$ and James Julson ${ }^{1}$ \\ 1 Department of Agricultural \& Biosystems Engineering, South Dakota State University, Brookings, SD 57007, \\ USA; xianhuizhao@usf.edu (X.Z.); shouyun.cheng@sdstate.edu (S.C.); james.julson@sdstate.edu (J.J.) \\ 2 Department of Chemical \& Biomedical Engineering, University of South Florida, Tampa, FL 33620, USA \\ * Correspondence: lin.wei@sdstate.edu; Tel.: +1-605-688-4179
}

Academic Editors: Rafael Luque, Pedro Maireles-Torres and Manuel López-Granados Received: 29 December 2016; Accepted: 7 March 2017; Published: 11 March 2017

\begin{abstract}
To address the issues of greenhouse gas emissions associated with fossil fuels, vegetable oilseeds, especially non-food oilseeds, are used as an alternative fuel resource. Vegetable oil derived from these oilseeds can be upgraded into hydrocarbon biofuel. Catalytic cracking and hydroprocessing are two of the most promising pathways for converting vegetable oil to hydrocarbon biofuel. Heterogeneous catalysts play a critical role in those processes. The present review summarizes current progresses and remaining challenges of vegetable oil upgrading to biofuel. The catalyst properties, applications, deactivation, and regeneration are reviewed. A comparison of catalysts used in vegetable oil and bio-oil upgrading is also carried out. Some suggestions for heterogeneous catalysts applied in vegetable oil upgrading to improve the yield and quality of hydrocarbon biofuel are provided for further research in the future.
\end{abstract}

Keywords: vegetable oil; hydrocarbon; biofuel; catalytic cracking; hydroprocessing; deactivation; regeneration

\section{Introduction}

The large utilization of fossil fuels has caused serious issues including national energy security, depleting oil reservoirs, and environmental pollutions [1,2]. Releasing large amount of greenhouse gases (GHG) is one of the biggest issues caused by burning fossil fuels [3]. To reduce GHG emissions, utilizing renewable energy resources to replace fossil fuels continues to grow. Biofuel produced from biomass has great potential as an alternative to fossil fuels [4,5]. Bio-oil is derived from the pyrolysis of biomass including switchgrass, pine wood and sawdust. Vegetable oil is extracted from vegetable oilseeds such as canola and camelina seeds [6]. The upgrading of bio-oil into hydrocarbon biofuel has faced many challenges including the bio-oil's high oxygen content, low heating value, and being corrosive to common metals, acidic, and thermally/chemically unstable $[7,8]$. Because of its high energy and low oxygen content, vegetable oil is easier to be converted into liquid biofuel than the bio-oil derived from cellulosic biomass [9]. Vegetable oil mainly consists of triglycerides and possesses similar carbon chains as the liquid fuel derived from fossil sources [10]. The triglycerides present in vegetable oil can be converted into hydrocarbons through the removal of oxygen to produce liquid biofuel. Sustainable biofuel produces low GHG emission and provides socioeconomic value to the local communities [11]. Biofuel is carbon neutral and environmentally friendly [1]. Vegetable oil can be upgraded to produce either hydrocarbon biofuel or biodiesel. Vegetable oil can be upgraded into methyl esters that are commonly called biodiesel [12]. However, biodiesel contains oxygen, gels at cold temperature and its energy density is relatively low, when compared to hydrocarbon biofuel that has high energy density with very little or no oxygen content [13]. The focus of this review is the hydrocarbon biofuel that is derived from catalytically upgrading of vegetable oil. 
The oilseed industry is a vast and growing enterprise all over the world. The United States leads the world in oilseed production and processing [12]. Soybeans, cottonseed, peanuts, and sunflower are major oilseed crops grown in the United States [4]. The existing vegetable oilseed capabilities in American north-central regions could provide about 58\% of the Navy's expected needs in 2020 [13]. Vegetable oilseeds are usually processed through cold press and solvent extraction technologies to produce vegetable oil, which is then upgraded to liquid hydrocarbon biofuel $[14,15]$. First generation oils are considered to be soybean and palm oils (derived from food crops). Second generation oils are considered to be camelina, jatropha and algal oils (derived from non-food crops) [14]. Vegetable oil contains primarily triglycerides that can be easily converted to liquid hydrocarbon biofuel [1]. Non-food vegetable oil does not compete with food and its sources could be classified into non-food plant oil, waste vegetable cooking oil, and oil produced from wastes derived from the processing of food oilseeds [16-18].

There are several methods for converting vegetable oil to biofuel including transesterification, fermentation, thermal cracking, catalytic cracking, and hydroprocessing. Each method has its advantages and disadvantages, but this study focuses on catalytic cracking and hydroprocessing. The catalytic cracking and hydroprocessing technologies are two typical pathways for converting bio-oil to hydrocarbon biofuel $[8,19]$. Catalytic cracking could be used to obtain a high yield of hydrocarbon biofuel from vegetable oil at a relatively lower reaction temperature [1,20]. In addition, catalytic cracking is a cost effective and simple technology to convert vegetable oil to hydrocarbon biofuel [21]. Hydroprocessing is widely used in the refineries and vegetable oil upgrading to remove oxygen through the introduction of $\mathrm{H}_{2}$ [22].

Hydrocarbon biofuels have the potential to reduce the greenhouse gas emissions. The use of hydrocarbon biofuels does not require many modifications to the existing fuel distribution infrastructure or vehicle engine [23]. Price, life cycle of biofuel, and the emission from engines are significant factors. Biofuel has many applications such as lubrication, hydraulic operating fluid, and heat absorption [24]. Several main factors determine the cost of hydrocarbon biofuel production including feedstock, chemical processing, refinement and transportation/distribution. The future development of hydrocarbon biofuel depends on significant cost reduction [23].

Although the feedstock supply dynamic is important to production economics, catalysts are also important in the chemical processing. Catalysts should be highly efficient and highly selective. Zeolite based catalysts are effectively used for vegetable oil cracking processes. For example, ZSM-5 has been used as a catalyst additive to improve the yield of light olefins [1]. Ishihara et al. studied the catalytic cracking of soybean oil over zeolite containing mesoporous silica-aluminas catalyst. They found that the straight-chained structure of a fatty acid could be effectively cracked on the acid sites of zeolites [25]. Taufiqurrahmi et al. studied the cracking of used palm oil over nanocrystalline zeolite beta and obtained a gasoline fraction yield of 35\% [9]. Zeolite based catalysts (e.g., HZSM-5, H-Y, $\mathrm{H}$-mordenite, etc.) have been used for the upgrading/refining of bio-oil $[8,26]$. $\mathrm{Al}_{2} \mathrm{O}_{3}$ based catalysts are conventional catalysts used for producing hydrocarbon biofuel through the hydroprocessing of vegetable oil [27]. Krar et al. studied the hydroprocessing of sunflower oil over $\mathrm{CoMo} / \mathrm{Al}_{2} \mathrm{O}_{3}$ catalysts. A $74 \%$ yield of targeted paraffin having a gas oil boiling range product was obtained [28]. Srifa et al. investigated the hydroprocessing of palm oil over $\mathrm{NiMoS}_{2} / \mathrm{Al}_{2} \mathrm{O}_{3}$ catalysts resulted in a yield of $90 \%$ of the bio-hydrogenated diesel [29]. In addition, there are some other types of catalysts (e.g., $\mathrm{Pd} / \mathrm{C}$ and $\mathrm{V}_{2} \mathrm{O}_{5}$ ) being used for the upgrading of vegetable oil to hydrocarbon biofuel.

The objective of this review is to evaluate and summarize the upgrading of vegetable oil to hydrocarbon biofuel. This review focuses on the upgrading of vegetable oil to hydrocarbon biofuel, and recent research of catalyzed vegetable oil upgrading in comparison with bio-oil upgrading. In addition, some properties of the catalysts, the catalyst deactivation and catalyst regeneration used in vegetable oil upgrading will be discussed. 


\section{Physicochemical Properties of Vegetable Oil}

Table 1 shows the typical properties of vegetable oil, including water content, acid number, viscosity, density, and higher heating value (HHV). The water content of most vegetable oils is low, between $0.03 \mathrm{wt} \%$ and $0.47 \mathrm{wt} \%$. Usually, the vegetable oil does not dissolve in water because the vegetable oil molecules are non-polar while the water molecules are polar. The water content of vegetable oil was much lower than that of bio-oil (15-30 wt \%) [8]. These vegetable oils have an acid number since some of the triglycerides present in the vegetable oils are decomposed to free fatty acids. The acid number of vegetable oils $(0.20-27.2 \mathrm{mg} \cdot \mathrm{KOH} / \mathrm{g})$ was lower than that of bio-oil $(998 \mathrm{mg}$ $\mathrm{KOH} / \mathrm{g}$ ) derived from pine sawdust [30]. The viscosity of vegetable oil is high due to its long carbon chain and large molecules with oxygen atoms. The viscosity of bio-oils was also high, ranging from $40 \mathrm{cP}$ to $100 \mathrm{cP}$ [8]. The densities of vegetable oil ranged between $0.84 \mathrm{~g} / \mathrm{mL}$ and $0.97 \mathrm{~g} / \mathrm{Ml}$. This was lower than that of bio-oil $(1.05-1.25 \mathrm{~g} / \mathrm{mL})$ [8]. The higher heating value of vegetable oils was high (between $37.1 \mathrm{MJ} / \mathrm{kg}$ and $40.6 \mathrm{MJ} / \mathrm{kg}$ ) when compared to that of bio-oil (16-19 MJ/kg) [8]. The high energy content of vegetable oil makes it an alternative fuel to replace diesel fuel for a short time use, but the deposition produced by the vegetable oil combustion is an issue for a long time use [4].

Table 1. Typical properties of vegetable oil.

\begin{tabular}{|c|c|c|c|c|c|c|}
\hline Vegetable Oil & $\begin{array}{c}\text { Water } \\
\text { Content } \\
\text { (wt \%) }\end{array}$ & $\begin{array}{c}\text { Acid } \\
\text { Number } \\
\text { (mg KOH/g) }\end{array}$ & $\begin{array}{c}\text { Viscosity } \\
\left(\mathrm{cP} \text { or } \mathrm{mm}^{2} / \mathrm{s}\right)\end{array}$ & $\begin{array}{c}\text { Density } \\
(\mathrm{g} / \mathrm{mL})\end{array}$ & $\begin{array}{c}\text { HHV } \\
(\mathrm{MJ} / \mathrm{kg})\end{array}$ & Ref. \\
\hline Carinata & 0.05 & 4.50 & $87.5 \mathrm{cP}$ & 0.88 & 40.3 & {$[31,32]$} \\
\hline Camelina & 0.08 & $1-5$ & $59.4 \mathrm{cP} @ 20^{\circ} \mathrm{C}$ & 0.89 & 39.4 & {$[21,33]$} \\
\hline Flax & 0.07 & 0.80 & $50.3 \mathrm{cP} @ 20^{\circ} \mathrm{C}$ & 0.91 & 39.1 & {$[34,35]$} \\
\hline Canola & 0.05 & 1.8 & $87.2 \mathrm{cP}$ & 0.91 & 39.8 & {$[34,36]$} \\
\hline Soybean & 0.06 & 0.20 & $32.6 \mathrm{~mm}^{2} / \mathrm{s} @ 40^{\circ} \mathrm{C}$ & 0.84 & 39.5 & {$[37-40]$} \\
\hline Sunflower & 0.06 & 1.8 & $77.3 \mathrm{cP}$ & 0.92 & 39.5 & {$[16,28]$} \\
\hline Terminalia belerica & 0.15 & 3.36 & $39.8 \mathrm{~mm}^{2} / \mathrm{s} @ 40^{\circ} \mathrm{C}$ & 0.93 & 37.5 & {$[38,41]$} \\
\hline Rubber seed & 1.50 & 25.1 & $57.9 \mathrm{~mm}^{2} / \mathrm{s}$ & 0.93 & 37.1 & [42-44] \\
\hline Jatropha & 3.28 & 27.2 & $46.8 \mathrm{~mm}^{2} / \mathrm{s} @ 30^{\circ} \mathrm{C}$ & 0.92 & 39.6 & {$[36,45,46]$} \\
\hline Palm & 0.47 & 4.80 & $48.1 \mathrm{~mm}^{2} / \mathrm{s}$ & 0.90 & 39.0 & [47-49] \\
\hline Rapeseed & $0.03-0.04$ & 1.14 & $35.2 \mathrm{~mm}^{2} / \mathrm{s}$ & 0.91 & 39.5 & {$[38,40,50-52]$} \\
\hline Crambe & - & 0.33 & $6.64 \mathrm{~mm}^{2} / \mathrm{s}$ & 0.89 & 40.6 & [40] \\
\hline Sesame & - & 0.55 & $25.8 \mathrm{~mm}^{2} / \mathrm{s} @ 40{ }^{\circ} \mathrm{C}$ & 0.90 & 39.5 & {$[53,54]$} \\
\hline Cottonseed & 0.03 & 0.30 & $58.2 \mathrm{cP}$ & 0.92 & 39.4 & {$[53,55,56]$} \\
\hline Karanja & - & 1.23 & $25.0 \mathrm{cP} @ 40^{\circ} \mathrm{C}$ & 0.97 & 38.4 & {$[57-59]$} \\
\hline Safflower & 0.04 & $0.97-9.24$ & $31.3 \mathrm{~mm}^{2} / \mathrm{s} @ 38{ }^{\circ} \mathrm{C}$ & $0.92-0.93$ & 39.5 & {$[12,52,55]$} \\
\hline Mustard & 0.03 & 0.55 & $73.0 \mathrm{~mm}^{2} / \mathrm{s} @ 25^{\circ} \mathrm{C}$ & 0.92 & 39.0 & {$[51,60-62]$} \\
\hline
\end{tabular}

Table 2 shows the element (carbon: C; hydrogen: H; oxygen: O; nitrogen: N; sulfur: S) content of vegetable oil. The carbon content of vegetable oils was between $69.0 \mathrm{wt} \%$ and $78.9 \mathrm{wt} \%$, which is higher than that of bio-oil (55-65 wt \%) [8]. The hydrogen content of vegetable oils was between $10.8 \mathrm{wt}$ $\%$ and $13.6 \mathrm{wt} \%$, which is higher than that of bio-oil (5-7 wt \%) [8]. The $\mathrm{H} / \mathrm{C}$ molar ratio of petroleum product is 2.0, which is in the range of the $\mathrm{H} / \mathrm{C}$ molar ratio of vegetable oils (between 1.64 and 2.37). However, the $\mathrm{H} / \mathrm{C}$ molar ratio of bio-oil was ranging from 0.92 to 1.53 [8]. The oxygen content of vegetable oils was between $10.5 \%$ and $14.5 \%$, which was much lower than that of bio-oil $(28 \%-40 \%)$ [8]. The nitrogen content of vegetable oils was not higher than $1.0 \mathrm{wt} \%$ and the nitrogen content of bio-oil was lower than $0.4 \mathrm{wt} \%$ [8]. The sulfur content of vegetable oils was very low (not higher than $0.15 \mathrm{wt} \%$ ) and the sulfur content of bio-oil was lower than $0.05 \mathrm{wt} \%$ [8]. The environmental impacts of aviation fuel include $\mathrm{CO}, \mathrm{CO}_{2}, \mathrm{H}_{2} \mathrm{O}, \mathrm{NO}_{x}$, hydrocarbons, primary PM2.5 (particulate matter 2.5), $\mathrm{SO}_{x}$, and aircraft noise [12]. Particulate matter is a mixture of solid particles and liquid droplets that are suspended in the atmosphere [63]. The low content of nitrogen and sulfur results in low $\mathrm{NO}_{x}$ and $\mathrm{SO}_{x}$ emission when burning the hydrocarbon biofuel derived from the vegetable oils and/or bio-oils. 
Table 2. The elemental content of vegetable oil.

\begin{tabular}{|c|c|c|c|c|c|c|}
\hline $\begin{array}{c}\text { Vegetable } \\
\text { Oil }\end{array}$ & $\begin{array}{c}\text { Carbon } \\
(w t \%)\end{array}$ & $\begin{array}{l}\text { Hydrogen } \\
\text { (wt \%) }\end{array}$ & $\begin{array}{c}\text { Oxygen } \\
(\mathrm{wt} \%)\end{array}$ & $\begin{array}{c}\text { Nitrogen } \\
(w t \%)\end{array}$ & Sulfur (wt \%) & References \\
\hline Carinata & 78.9 & 11.8 & - & 0.24 & - & [31] \\
\hline Camelina & 78.5 & 11.9 & 12.4 & 0.29 & - & [21] \\
\hline Flax & 78.3 & 11.8 & 10.5 & 0.16 & - & [34] \\
\hline Canola & 78.3 & 12.2 & 11.5 & 0.43 & 0.02 & {$[34,64]$} \\
\hline Soybean & 77.6 & 11.9 & 11.0 & - & 0.01 & {$[37,39]$} \\
\hline Sunflower & 77.9 & 12.5 & 10.9 & 0.15 & $<$ detection limit & {$[10,16,28]$} \\
\hline Jatropha & 76.1 & 11.8 & 12.0 & 0.20 & - & [65] \\
\hline Palm & - & - & - & - & 0.01 & [39] \\
\hline Rapeseed & 77.2 & 13.6 & 10.9 & 0.01 & 0.15 & {$[50,51]$} \\
\hline Sesame & 69.0 & - & - & - & $<$ detection limit & [54] \\
\hline Cottonseed & - & - & - & - & 0.01 & [66] \\
\hline Karanja & 73.7 & 10.8 & 14.5 & 1.00 & $<$ detection limit & [57] \\
\hline Safflower & - & - & - & - & $<$ detection limit & [52] \\
\hline Mustard & - & - & 11.0 & - & $<$ detection limit & {$[51,60]$} \\
\hline
\end{tabular}

Table 3 shows the main fatty acid composition of vegetable oil. Biomass has different chemical properties, but most vegetable oils contain mainly C16 and C18 [63]. The fatty acid composition of vegetable oils is one significant factor affecting the yield and quality of hydrocarbon biofuel produced. Fatty acids of vegetable oil have an influence on its viscosity, melting point and boiling point. In addition, fatty acids influence the performance of catalysts (e.g., lifetime, selectivity and activity) during vegetable oil upgrading [16,34]. All vegetable oils contain both saturated and unsaturated fatty acids. The saturated fatty acids contain mainly palmitic acid $\left(\mathrm{C}_{16} \mathrm{H}_{32} \mathrm{O}_{2}\right)$, stearic acid $\left(\mathrm{C}_{18} \mathrm{H}_{36} \mathrm{O}_{2}\right)$, arachidic acid $\left(\mathrm{C}_{20} \mathrm{H}_{40} \mathrm{O}_{2}\right)$ and docosanoic acid $\left(\mathrm{C}_{22} \mathrm{H}_{44} \mathrm{O}_{2}\right)$. The unsaturated fatty acids contain mainly oleic acid $\left(\mathrm{C}_{18} \mathrm{H}_{34} \mathrm{O}_{2}\right)$ and linoleic acid $\left(\mathrm{C}_{18} \mathrm{H}_{32} \mathrm{O}_{2}\right)$. The non-food vegetable oil including crambe oil, camelina oil, carinata oil, and jatropha oil does not challenge the food ecosystem and production [67]. However, some vegetable oils such as soybean oil and canola oil could be used as food. In the future, a large amount of non-food vegetable oils with effective cost and suitable fatty acid composition need to be selected and developed. The fatty acid content of bio-oils ranges approximately from $0.5 \%$ to $22 \%$ [19]. Compared to vegetable oil, bio-oil is a more complicated mixture containing many components such as acids, alcohols, aldehydes, ethers, furans, ketones, and phenols.

Table 3. Main fatty acid composition of vegetable oil (\%).

\begin{tabular}{cccccccccccc}
\hline Vegetable Oil & C14:0 & C16:0 & C18:0 & C18:1 & C18:2 & C18:3 & C20:0 & C20:1 & C22:0 & C22:1 & Ref. \\
\hline Carinata & - & 7.74 & 19.9 & 11.3 & 10.5 & - & - & - & - & 48.0 & {$[31]$} \\
Camelina & - & $5.3-6.8$ & $2.5-2.7$ & $12.6-18.6$ & $14.3-19.6$ & $32.6-38.41 .2-1.5$ & $12.4-16.80 .2-0.3$ & $2.3-2.9$ & {$[33]$} \\
Flax & - & 6.58 & 4.43 & 18.5 & 17.3 & 53.2 & - & - & - & - & {$[35]$} \\
Canola & - & 4 & 2 & 60 & 20 & 10 & - & 1.6 & - & 2.4 & {$[68]$} \\
Soybean & - & 14 & 4 & 24 & 52 & 6 & - & - & - & - & {$[39]$} \\
Sunflower & 0.09 & 6.33 & 3.45 & 21.6 & 67.8 & 0.09 & 0.23 & 0.13 & 0.22 & - & {$[28]$} \\
Terminalia belerica & - & 32.8 & 6.4 & 31.3 & 28.8 & - & 0.3 & - & - & - & {$[41]$} \\
Rubber seed & - & 10.2 & 8.7 & 24.6 & 39.6 & 16.3 & - & - & - & - & {$[69]$} \\
Jatropha & - & 15.9 & 6.90 & 41.1 & 34.7 & 0.30 & - & 0.20 & - & - & {$[36]$} \\
Palm & - & 35 & 6 & 44 & 15 & - & - & - & - & - & {$[39]$} \\
Rapeseed & - & 18.9 & 3.4 & 65.8 & 9.2 & 0.2 & - & - & - & - & {$[51]$} \\
Crambe & 0.1 & 2.0 & 0.9 & 17.2 & 8.2 & 5.0 & 1.1 & 3.7 & 2.2 & 57.2 & {$[40]$} \\
Sesame & - & 13.1 & 3.9 & 52.8 & 30.2 & - & - & - & - & - & {$[55]$} \\
Cottonseed & - & 28 & 1 & 13 & 58 & - & - & - & - & - & {$[55]$} \\
Karanja & - & 11.7 & 7.5 & 53.3 & 16.6 & 2.6 & 1.7 & 1.1 & 4.45 & - & {$[58]$} \\
Safflower & - & 9 & 2 & 12 & 78 & - & - & - & - & - & {$[55]$} \\
Mustard & - & 22.0 & 9.4 & 34.5 & 6.3 & 22.5 & - & - & - & - & {$[51]$} \\
\hline
\end{tabular}

\section{Upgrading of Vegetable Oil to Hydrocarbon Biofuel}

\subsection{Catalytic Cracking of Vegetable Oil}

Table 4 shows recent progresses in the catalytic cracking of vegetable oil to hydrocarbon biofuel. The typical reaction temperature for catalytic cracking of vegetable oil ranged between $380{ }^{\circ} \mathrm{C}$ and 
$525{ }^{\circ} \mathrm{C}$. During preliminary catalytic cracking experiments, vegetable oil was difficult to crack at a low reaction temperature. However, the yield of liquid product was low due to an increase in the formation of gases if the reaction temperature was too high $[8,70]$. During the catalytic cracking of bio-oil over HZSM- 5 catalysts, $450{ }^{\circ} \mathrm{C}$ was considered as a suitable reaction temperature for maximizing the biofuel yield and minimizing the char/coke yields [8]. The catalytic cracking of vegetable oil could be carried out at different pressures ranging from $1 \mathrm{~atm}$ to $99 \mathrm{~atm}$. It seems a high pressure (e.g., 20-99 atm) could lower the reaction temperature when catalytically cracking sunflower oil to diesel oil-like hydrocarbons [10]. In addition to reaction temperature and pressure, space velocity and catalyst-to-oil ratio are significant factors for upgrading vegetable oil. Operating conditions and feedstock composition can affect the catalyst deactivation [71]. The most common reactor used for the catalytic cracking of vegetable oil is a fixed-bed reactor. It is good for continuous vegetable oil feeding. Reactor configuration is significant in the mass transfer of vegetable oil feed and reaction rates. Clogging, entrainment and channeling are major issues in reactors due to irregular distribution of materials [72]. Shape selective zeolite-based catalysts and metal oxides were used for catalytic cracking of vegetable oil. The cracking and aromatization reactions are usually catalyzed by Brønsted acid sites of zeolites [73,74]. Zeolites contain acid sites, and have high surface area and adsorption capacity [75]. However, some zeolite based catalysts are plagued by catalyst deactivation, short lifetime, and product contamination.

Table 4. Recent progresses in catalytic cracking of vegetable oil to hydrocarbon biofuel.

\begin{tabular}{|c|c|c|c|c|c|c|c|}
\hline $\begin{array}{l}\text { Vegetable } \\
\text { Oil }\end{array}$ & Catalyst & Conditions & Reactor & Main Product & $\begin{array}{l}\text { Product } \\
\text { Yield } \\
\text { (wt \%) }\end{array}$ & $\begin{array}{l}\text { Coke } \\
\text { Yield } \\
(w t \%)\end{array}$ & Ref. \\
\hline Carinata & Zn/Na-ZSM-5 & $450{ }^{\circ} \mathrm{C}, 1 \mathrm{~atm}$ & $\begin{array}{l}\text { Fixed-bed } \\
\text { reactor }\end{array}$ & $\begin{array}{l}\text { Hydrocarbon } \\
\text { biofuel }\end{array}$ & $43.7-62.9$ & $3.40-8.51$ & [32] \\
\hline Sunflower & $\mathrm{V}_{2} \mathrm{O}_{5}$ & $330-380^{\circ} \mathrm{C}$ & Borosil flask & $\begin{array}{l}\text { Organic liquid } \\
\text { product }\end{array}$ & $88.7-92.1$ & - & [76] \\
\hline Sunflower & $\begin{array}{c}\text { Metal oxides }\left(\mathrm{Co}_{3} \mathrm{O}_{4}\right. \\
\mathrm{KOH} ; \mathrm{MoO}_{3} ; \mathrm{NiO} ; \\
\left.\mathrm{V}_{2} \mathrm{O}_{5} ; \mathrm{ZnO}\right)\end{array}$ & $320-390^{\circ} \mathrm{C}$ & Borosil flask & $\begin{array}{l}\text { Organic liquid } \\
\text { product }\end{array}$ & $55.1-87.6$ & - & [7] \\
\hline Rapeseed & $\begin{array}{c}\text { Fluid catalytic cracking } \\
\text { equilibrium catalyst } \\
\text { (FCC-ECAT) }\end{array}$ & $525^{\circ} \mathrm{C}$ & $\begin{array}{l}\text { Microactivity } \\
\text { test reactor }\end{array}$ & $\begin{array}{l}\text { Liquid organic } \\
\text { phase }\end{array}$ & $50.1-53.8$ & $6.3-16.1$ & [50] \\
\hline Rapeseed & $\begin{array}{l}\text { Fluid catalytic cracking } \\
\text { ZSM-5 (FCC-ZSM-5) }\end{array}$ & $525^{\circ} \mathrm{C}$ & $\begin{array}{l}\text { Microactivity } \\
\text { test reactor }\end{array}$ & $\begin{array}{l}\text { Liquid organic } \\
\text { phase }\end{array}$ & $47.4-55.8$ & $4.7-10.4$ & [50] \\
\hline Palm & $\mathrm{Na}_{2} \mathrm{CO}_{3}$ & $450^{\circ} \mathrm{C}, 1 \mathrm{~atm}$ & $\begin{array}{l}\text { Sludge bed } \\
\text { reactor }\end{array}$ & $\begin{array}{l}\text { Organic liquid } \\
\text { product }\end{array}$ & 65.9 & 1.4 & [47] \\
\hline Camelina & ZSM-5-Zn & $500^{\circ} \mathrm{C}, 1 \mathrm{~atm}$ & $\begin{array}{l}\text { Fixed-bed } \\
\text { reactor }\end{array}$ & $\begin{array}{l}\text { Hydrocarbon } \\
\text { biofuel }\end{array}$ & $15.0-19.6$ & $4.81-7.38$ & [21] \\
\hline Jatropha & $\mathrm{CaO}$ & $400^{\circ} \mathrm{C}, 3 \mathrm{~atm}$ & Batch reactor & $\begin{array}{l}\text { Hydrocarbon } \\
\text { biofuel }\end{array}$ & 83 & - & [65] \\
\hline Vegetable & HZSM-5 & $500^{\circ} \mathrm{C}, 1 \mathrm{~atm}$ & $\begin{array}{l}\text { Fixed-bed } \\
\text { reactor }\end{array}$ & Biofuel & $\sim 45$ & $\sim 8$ & [77] \\
\hline Palm & Fe-Zn-Cu-ZSM-5 & $450{ }^{\circ} \mathrm{C}$ & $\begin{array}{l}\text { Lab scale } \\
\text { reactor }\end{array}$ & Biogasoline & 59 & - & [1] \\
\hline Sunflower & $\begin{array}{c}\text { Combination of } \\
\mathrm{Pt}-\mathrm{Ni} / \mathrm{Al}_{2} \mathrm{O}_{3} \text { and } \mathrm{Pd} / \mathrm{C}\end{array}$ & $\begin{array}{c}250-300{ }^{\circ} \mathrm{C}, \\
20-99 \mathrm{~atm}\end{array}$ & $\begin{array}{c}\text { Fixed-bed } \\
\text { batch reactor }\end{array}$ & $\begin{array}{l}\text { Diesel oil-like } \\
\text { hydrocarbon }\end{array}$ & $21.9-48.8$ & - & [10] \\
\hline $\begin{array}{l}\text { Rubber } \\
\text { seed }\end{array}$ & $\begin{array}{l}\text { MNC-13 (mesoporous } \\
\text { molecular sieves) }\end{array}$ & $410^{\circ} \mathrm{C}$ & $\begin{array}{l}\text { Glass vessel } \\
\text { reactor }\end{array}$ & $\begin{array}{l}\text { Liquid hydrocarbon } \\
\text { fuel }\end{array}$ & 74.9 & 4.90 & [43] \\
\hline Soybean & Mesoporous HY zeolite & $500{ }^{\circ} \mathrm{C}$ & $\begin{array}{l}\text { Fixed-bed } \\
\text { reactor }\end{array}$ & Gasoline (C5-C11) & $\sim 26$ & - & [25] \\
\hline
\end{tabular}

During the catalytic cracking of vegetable oil, several reactions including decarbonylation, decarboxylation, and deoxidation took place to remove the oxygen atoms from the triglyceride molecules [21]. The hydrocarbon biofuels produced by the catalytic cracking of vegetable oil included organic liquid product, biogasoline, and diesel oil-like hydrocarbons. Similar to bio-oil upgrading, the liquid/coke yields during the catalytic cracking of vegetable oil were highly dependent on the 
catalyst species and operation conditions [19]. It was reported that the catalytic cracking of vegetable oil yielded more total hydrocarbon liquid product when compared to catalytic cracking of bio-oil [8]. Catalytic cracking of bio-oil can be divided into traditional catalytic cracking and a combination of catalytic pyrolysis and catalytic cracking. The combination of catalytic pyrolysis and catalytic cracking refers to a biomass pyrolysis reactor for bio-oil production followed by a subsequent cracking reactor for converting bio-oil to biofuel. It was demonstrated that the combination of catalytic pyrolysis and catalytic cracking technology was superior for improving the biofuel yield and quality compared to traditional catalytic cracking technology [78]. Table 5 shows the conversion efficiency and mass balance of vegetable oil based feedstock upgrading over various catalysts. Dupain et al. [79] studied the catalytic cracking of rapeseed oil over FCC catalyst and obtained at $93 \%$ of high conversion of rapeseed oil. In our previous study on the catalytic cracking of carinata oil over Zn/Na-ZSM- 5 catalyst, the mass balance was 95-96 wt \% [32]. Twaiq et al. [80] investigated the liquid fuel production from the catalytic cracking of palm oil over zeolite catalysts. Stainless steel reactor was used with a space velocity of $2.5 \mathrm{~h}^{-1}$. The palm oil conversion obtained over HZSM-5 and MCM-41 was 94\%-97\%, and $85 \%-93 \%$, respectively. Nam et al. [81] studied the biofuel production through the catalytic cracking of vegetable oil sludge over MC-ZSM-5/MCM-41 catalyst in a micro-activity test system. The conversion rate of the vegetable oil sludge was $85 \%-93 \%$.

Table 5. The conversion efficiency and mass balance of vegetable oil based feedstock upgrading over different catalysts.

\begin{tabular}{|c|c|c|c|c|c|c|}
\hline Feedstock & Catalyst & $\begin{array}{l}\text { Weight Hourly } \\
\text { Space Velocity } \\
\left(h^{-1}\right)\end{array}$ & Reactor & $\begin{array}{c}\text { Mass } \\
\text { Balance } \\
\text { (wt \%) }\end{array}$ & $\begin{array}{l}\text { Conversion } \\
\text { Rate (wt \%) }\end{array}$ & Ref. \\
\hline Rapeseed oil & FCC & - & $\begin{array}{l}\text { Micro-riser } \\
\text { reactor }\end{array}$ & - & 93 & [79] \\
\hline Carinata oil & $\mathrm{Zn} / \mathrm{Na}-\mathrm{ZSM}-5$ & - & $\begin{array}{l}\text { Fixed-bed } \\
\text { reactor }\end{array}$ & $95-96$ & - & [32] \\
\hline Palm oil & HZSM-5 & 2.5 & $\begin{array}{c}\text { Stainless } \\
\text { steel reactor }\end{array}$ & - & $94-97$ & {$[80]$} \\
\hline Palm oil & MCM-41 & 2.5 & $\begin{array}{c}\text { Stainless } \\
\text { steel reactor }\end{array}$ & - & $85-93$ & [80] \\
\hline $\begin{array}{l}\text { Vegetable oil } \\
\text { sludge }\end{array}$ & MC-ZSM-5/MCM-4 & -41 & $\begin{array}{l}\text { Micro-activity } \\
\text { test system }\end{array}$ & - & 82 & [81] \\
\hline Palm oil & REY catalyst & - & $\begin{array}{l}\text { Transport } \\
\text { riser reactor }\end{array}$ & - & $55-94$ & [82] \\
\hline $\begin{array}{c}\text { Palm oil } \\
\text { based fatty } \\
\text { acid mixture }\end{array}$ & SBA-15 & 2.5 & $\begin{array}{l}\text { Fixed-bed } \\
\text { reactor }\end{array}$ & - & 61 & [83] \\
\hline Carinata oil & $\mathrm{Mo}-\mathrm{Zn} / \mathrm{Al}_{2} \mathrm{O}_{3}$ & - & $\begin{array}{l}\text { Autoclave } \\
\text { reactor }\end{array}$ & - & $93-94$ & [31] \\
\hline $\begin{array}{c}\text { Waste } \\
\text { vegetable oil }\end{array}$ & $\begin{array}{l}\mathrm{NiMo} / \mathrm{Al}_{2} \mathrm{O}_{3} \\
\mathrm{CoMo} / \mathrm{Al}_{2} \mathrm{O}_{3}\end{array}$ & 2.8 & $\begin{array}{l}\text { Autoclave } \\
\text { reactor }\end{array}$ & - & 99 & [84] \\
\hline Vegetable oil & $\begin{array}{c}\mathrm{NiMo} / \mathrm{Al} 2 \mathrm{O} 3 \\
\mathrm{Mo} / \mathrm{Al} 2 \mathrm{O} 3 \\
\mathrm{Ni} / \mathrm{Al} 2 \mathrm{O} 3\end{array}$ & $0.25-4$ & $\begin{array}{l}\text { Fixed-bed } \\
\text { reactor }\end{array}$ & - & 30-100 & [85] \\
\hline Vegetable oil & CoMo/OMA & $1.5-2$ & $\begin{array}{l}\text { Fixed-bed } \\
\text { reactor }\end{array}$ & - & 75-95 & [86] \\
\hline Vegetable oil & $\mathrm{Mo}_{2} \mathrm{C} / \mathrm{CNTs}$ & - & $\begin{array}{l}\text { Stainless } \\
\text { steel } \\
\text { autoclave }\end{array}$ & - & $31-100$ & [87] \\
\hline Vegetable oil & Pt/zeolite & 1 & $\begin{array}{l}\text { Fixed-bed } \\
\text { reactor }\end{array}$ & - & 100 & {$[88]$} \\
\hline $\begin{array}{l}\text { Sunflower } \\
\text { oil }\end{array}$ & ZSM-5 & 3 & $\begin{array}{l}\text { Fixed-bed } \\
\text { reactor }\end{array}$ & $\sim 97$ & - & [17] \\
\hline Vegetable oil & Ni-Mo based & 7.6 & $\begin{array}{l}\text { Fixed-bed } \\
\text { reactor }\end{array}$ & $>95$ & 100 & {$[36]$} \\
\hline
\end{tabular}


Figure 1 shows a proposed reaction pathway for the catalytic cracking of vegetable oil to hydrocarbon biofuel. Firstly, the unsaturated triglycerides and saturated triglycerides are decomposed to form fatty acids through either a carbonium ion or free-radical mechanism. The decomposition is a relatively fast process depending on the reaction temperature. Secondly, some of the fatty acids are dehydrated to form water. The formation of water required hydrogen atoms, which were donated by the hydrocarbon chains of fatty acids. The gases including $\mathrm{H}_{2}, \mathrm{CO}, \mathrm{CO}_{2}$ and light hydrocarbons (C1-C5) were produced through deoxygenation, dehydrogenation, decarboxylation and decarbonylation. During the catalytic cracking of bio-oil, the formation of $\mathrm{CO}, \mathrm{CO}_{2}$ and $\mathrm{H}_{2} \mathrm{O}$ were derived from these oxygen removal reactions [19]. The hydrocarbon biofuel was obtained through the cracking and deoxygenation reactions. The cracking might take place on the external surface and/or within the internal pore structure of catalysts to produce hydrocarbons and oxygenates. Thirdly, some of the hydrocarbons produced form coke through polymerization. In addition, the direct condensation of vegetable oil forms coke $[21,79,89,90]$. The reactions during catalytic cracking of bio-oil include hydrogen transfer, $\mathrm{C}-\mathrm{C}$ bond cleavage, dehydration, isomerization, decarbonylation and decarboxylation [91]. The main products of catalytic cracking of bio-oil over zeolite based catalysts were liquid oil, water, coke and gases [8]. Coke presents a serious challenge for both the catalytic cracking of vegetable oil and bio-oil since it could deactivate the catalysts. Loading metals to zeolites that tune the catalyst selectivity, co-feeding of hydrogen-rich feedstocks, and optimizing the upgrading operation conditions would be helpful for reducing the coke formation [19]. A certain amount of gas product is also a challenge for the catalytic cracking of vegetable oil to liquid biofuel. Modifying catalysts, optimizing upgrading operation conditions and recycling gases (e.g., tri-reforming of gases to syngas for Fischer-Tropsch synthesis) might be beneficial.
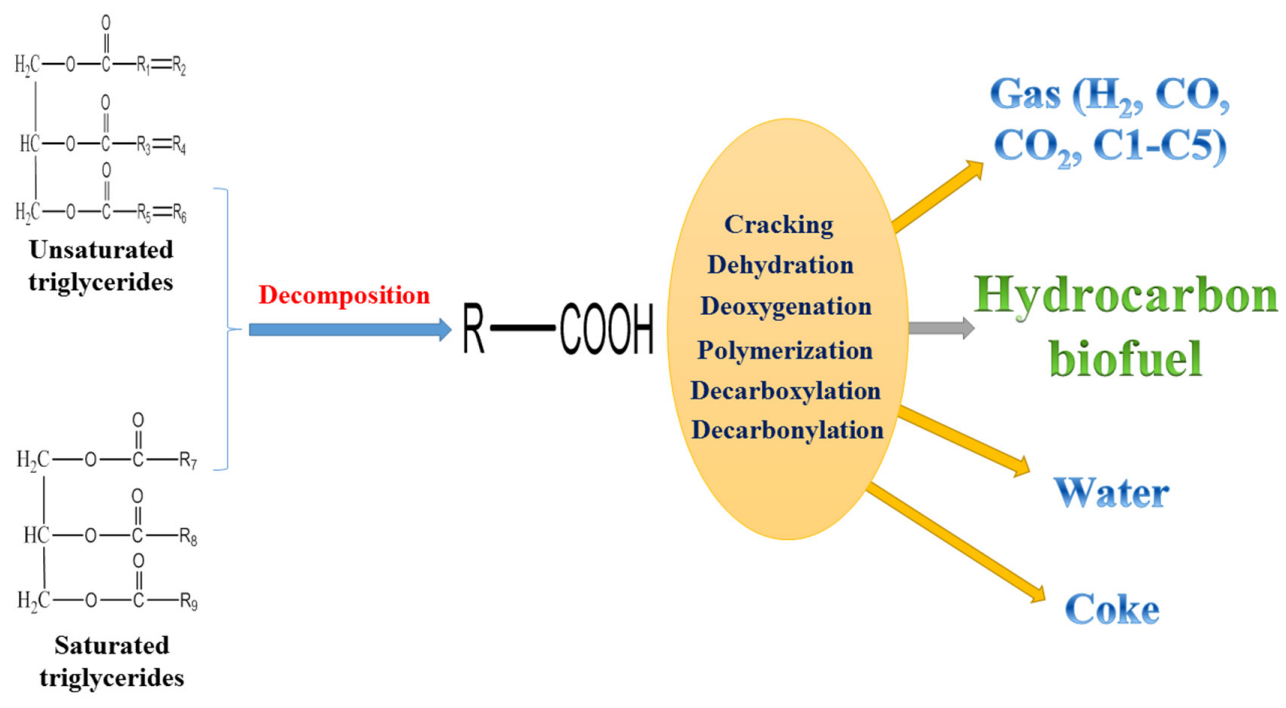

Figure 1. A proposed reaction pathway in the catalytic cracking of vegetable oil to hydrocarbon biofuel.

\subsection{Hydroprocessing of Vegetable Oil}

Table 6 shows the recent progresses in hydroprocessing of vegetable oil to produce hydrocarbon biofuel. Hydrogenation and other reactions crack complicated organic molecules to simpler molecules during the hydroprocessing process [75]. The typical reaction temperature for hydroprocessing of vegetable oil was between $300{ }^{\circ} \mathrm{C}$ and $390{ }^{\circ} \mathrm{C}$. Hydroprocessing of soybean oil was studied over NiMo/ZSM-5 based catalysts at a high reaction temperature of $450{ }^{\circ} \mathrm{C}$ [92]. The reaction temperature used for the hydroprocessing of bio-oil was usually $250-450{ }^{\circ} \mathrm{C}$ [19]. Temperature is a significant factor for the hydroprocessing of vegetable oil since high temperature favors coke formation [71]. The hydroprocessing of vegetable oil was usually carried out at high pressures, between $19 \mathrm{~atm}$ and $79 \mathrm{~atm}$. The pressure used for the hydroprocessing of bio-oil was usually 
74-296 atm [19]. High pressure of $\mathrm{H}_{2}$ may help slow the coke formation rate [71]. The catalysts used for the hydroprocessing of vegetable oil were mainly $\mathrm{Al}_{2} \mathrm{O}_{3}$-based catalysts, which might be due to the high surface area and acidity of $\mathrm{Al}_{2} \mathrm{O}_{3}$ [27,93]. In addition, some zeolites have been investigated for the vegetable oil cracking. The larger mesopores of mesoporous zeolites (e.g., $\mathrm{Ni}$ /mesoporous-Y and Ni/mesoporous-HZSM-5) may facilitate the transport of bulky vegetable oil molecules to catalyst active sites [94]. The vegetable oil upgrading conditions have an effect on catalyst stability and performance [71]. Hydroprocessing could be used to remove oxygen, sulfur, nitrogen, and metals from vegetable oil and bio-oil. The high oxygen content of many oxygenates, such as acids, esters and phenols, in bio-oil could be removed largely through the introduction of $\mathrm{H}_{2}$. During the hydroprocessing of vegetable oil, several main reactions including cracking, hydrogenation, decarbonylation, decarboxylation, and hydrodeoxygenation took place to convert the triglyceride molecules to hydrocarbons. Similar reactions occurred during the hydroprocessing of bio-oil. The deoxygenation during the hydroprocessing can result in increased hydrocarbon content [30]. Vegetable oil can become more saturated through introducing $\mathrm{H}_{2}[19,31,89]$. However, minimizing the amount of $\mathrm{H}_{2}$ is a goal for reducing cost [71]. The hydrocarbon biofuels produced from the hydroprocessing of vegetable oil mainly include organic product, green diesel, jet fuel and biohydrogenated diesel. The hydrocarbon biofuel yield obtained from the hydroprocessing of vegetable oil can be as high as $94 \mathrm{wt} \%$, and the coke yield was very low or even negligible. The liquid product yield obtained from the hydroprocessing of bio-oil can also be very high, reaching $99 \mathrm{wt} \%$ [19]. Solvent (e.g., methanol or ethanol) plays a significant role in the hydroprocessing of bio-oil since a suitable solvent addition can help resolve the bio-oil feeding issue and improve the overall reaction efficiency [6]. In our previous study on the hydroprocessing of carinata oil, $\mathrm{Mo}-\mathrm{Zn} / \mathrm{Al}_{2} \mathrm{O}_{3}$ was used as the catalyst. The conversion rate of the carinata oil was $93 \%-94 \%$ [31]. Toba et al. [84] studied the hydrodeoxygenation of waste vegetable oil over sulfide catalysts. An autoclave reactor was used and the conversion rate of waste vegetable oil was $99 \%$. The hydrotreatment of vegetable oil over the $\mathrm{Pt} /$ zeolite catalyst was investigated by Wang et al. [88]. A fixed-bed reactor was utilized with a space velocity of $1 \mathrm{~h}^{-1}$. The conversion rate of the vegetable oil was $100 \%$. Hydrotreatment of vegetable oil over Ni-Mo based catalysts was studied by Liu et al. [36]. A fixed-bed reactor was used with a space velocity of $7.6 \mathrm{~h}^{-1}$. The mass balance was higher than $95 \%$ and the vegetable oil conversion rate was $100 \%$.

Table 6. Recent progresses in hydroprocessing of vegetable oil to hydrocarbon biofuel.

\begin{tabular}{|c|c|c|c|c|c|c|c|}
\hline $\begin{array}{l}\text { Vegetable } \\
\text { Oil }\end{array}$ & Catalyst & Conditions & Reactor & Main Product & $\begin{array}{l}\text { Product } \\
\text { Yield } \\
\text { (wt \%) }\end{array}$ & $\begin{array}{l}\text { Coke } \\
\text { Yield } \\
(w t \%)\end{array}$ & Ref. \\
\hline Sunflower & $\mathrm{Co}-\mathrm{Mo} / \mathrm{Al}_{2} \mathrm{O}_{3}$ & $\begin{array}{c}300-380{ }^{\circ} \mathrm{C}, 20-79 \\
\text { atm }\end{array}$ & $\begin{array}{l}\text { High pressure } \\
\text { reactor }\end{array}$ & Organic product & $83.4-93.3$ & - & [28] \\
\hline $\begin{array}{l}\text { Refined } \\
\text { sunflower }\end{array}$ & $\mathrm{Ni}-\mathrm{Mo} / \mathrm{Al}_{2} \mathrm{O}_{3}$ & $360^{\circ} \mathrm{C} 59 \mathrm{~atm}$ & $\begin{array}{c}\text { High } \\
\begin{array}{c}\text { pressure-trickle bed } \\
\text { reactor }\end{array}\end{array}$ & Green diesel & - & - & [95] \\
\hline Jatropha & $\begin{array}{l}\mathrm{Ni}^{-\mathrm{H}_{3}} \mathrm{PW}_{12} / \text { nano- } \\
\text { hydroxyapatite }\end{array}$ & $360^{\circ} \mathrm{C}, 30 \mathrm{~atm}$ & Fixed-bed reactor & $\begin{array}{l}\text { Liquid product } \\
\text { oil }\end{array}$ & 83.4 & - & [27] \\
\hline Canola & $\mathrm{NiMo} / \mathrm{SiO}_{2}-\mathrm{Al}_{2} \mathrm{O}_{3}$ & $350^{\circ} \mathrm{C}, 39 \mathrm{~atm}$ & $\begin{array}{l}\text { High-pressure } \\
\text { fixed-bed reactor }\end{array}$ & $\begin{array}{l}\text { Biohydrogenated } \\
\text { diesel }\end{array}$ & 81.4 & - & [36] \\
\hline Carinata & $\mathrm{Mo}-\mathrm{Zn} / \mathrm{Al}_{2} \mathrm{O}_{3}$ & $350^{\circ} \mathrm{C}, 20 \mathrm{~atm}$ & Batch reactor & $\begin{array}{l}\text { hydrocarbon } \\
\text { biofuel }\end{array}$ & $92.6-93.5$ & $<0.60$ & [31] \\
\hline Canola & $\mathrm{Pd} / \mathrm{C}$ & $300^{\circ} \mathrm{C}, 19 \mathrm{~atm}$ & $\begin{array}{l}\text { Fed-batch Parr } \\
\quad \text { reactor }\end{array}$ & $\begin{array}{l}\text { hydrocarbon } \\
\text { fuel }\end{array}$ & - & - & [96] \\
\hline Soybean & $\begin{array}{l}\text { NiMo/ZSM-5 } \\
\text { carbide; } \\
\text { NiMo/ZSM-5 } \\
\text { nitride }\end{array}$ & $360-450{ }^{\circ} \mathrm{C}, 44 \mathrm{~atm}$ & Fixed-bed reactor & $\begin{array}{l}\text { hydrocarbon } \\
\text { fuel }\end{array}$ & $\sim 50$ & - & [92] \\
\hline Karanja & $\mathrm{Ni} / \mathrm{Al}_{2} \mathrm{O}_{3}$ & $380^{\circ} \mathrm{C}, 35 \mathrm{~atm}$ & Semi-batch reactor & Green diesel & 80 & - & [57] \\
\hline Palm & $\mathrm{Ni} /$ mesoporous-Y & $390^{\circ} \mathrm{C}, 30 \mathrm{~atm}$ & Batch reactor & Jet range alkane & 31 & - & [94] \\
\hline
\end{tabular}


Figure 2 shows the proposed main reactions for hydroprocessing of vegetable oil over a $\mathrm{Al}_{2} \mathrm{O}_{3}$ based catalyst. The double bonds in unsaturated vegetable oil triglycerides were hydrogenated to saturated triglycerides. The saturated vegetable oil triglycerides were then cleaved to fatty acids. Some of the fatty acids formed oxidants including aldehydes, alcohols, and ketones through the hydrodeoxygenation [31]. Removing oxygen is the first step for hydroprocessed renewable fuel production. After that, a mixture of straight chain, branched chain, and cyclic paraffinic hydrocarbons are obtained [63]. Some of the fatty acids yielded $\mathrm{CO}_{2}$ and hydrocarbons through decarboxylation. Some of the fatty acids produced $\mathrm{CO}, \mathrm{H}_{2} \mathrm{O}$ and hydrocarbons through hydro-decarbonylation. Some of the hydrocarbons obtained were cracked to light hydrocarbons (C1-C6) [29,97,98]. During the hydroprocessing of bio-oil, multiple reactions such as hydrogenolysis, hydrogenation, hydrodeoxygenation, decarbonylation, decarboxylation, hydrocracking and polymerization took place. These reactions produce a large amount of coke, tar and char, which could cause the catalyst deactivation and reactor clogging $[19,99]$. Besides catalytic cracking and hydroprocessing, emulsification and steam reforming/Fischer-Tropsch are two other technologies for upgrading bio-oil to biofuel [71]. Developing appropriate catalysts with high stability in harsh conditions and reducing the cost of the $\mathrm{H}_{2}$ introduction need to be further investigated for hydroprocessing of vegetable oil to hydrocarbon biofuel. In addition, the understanding of the influence of fatty acids present in the vegetable oil on oil upgrading needs to be advanced.

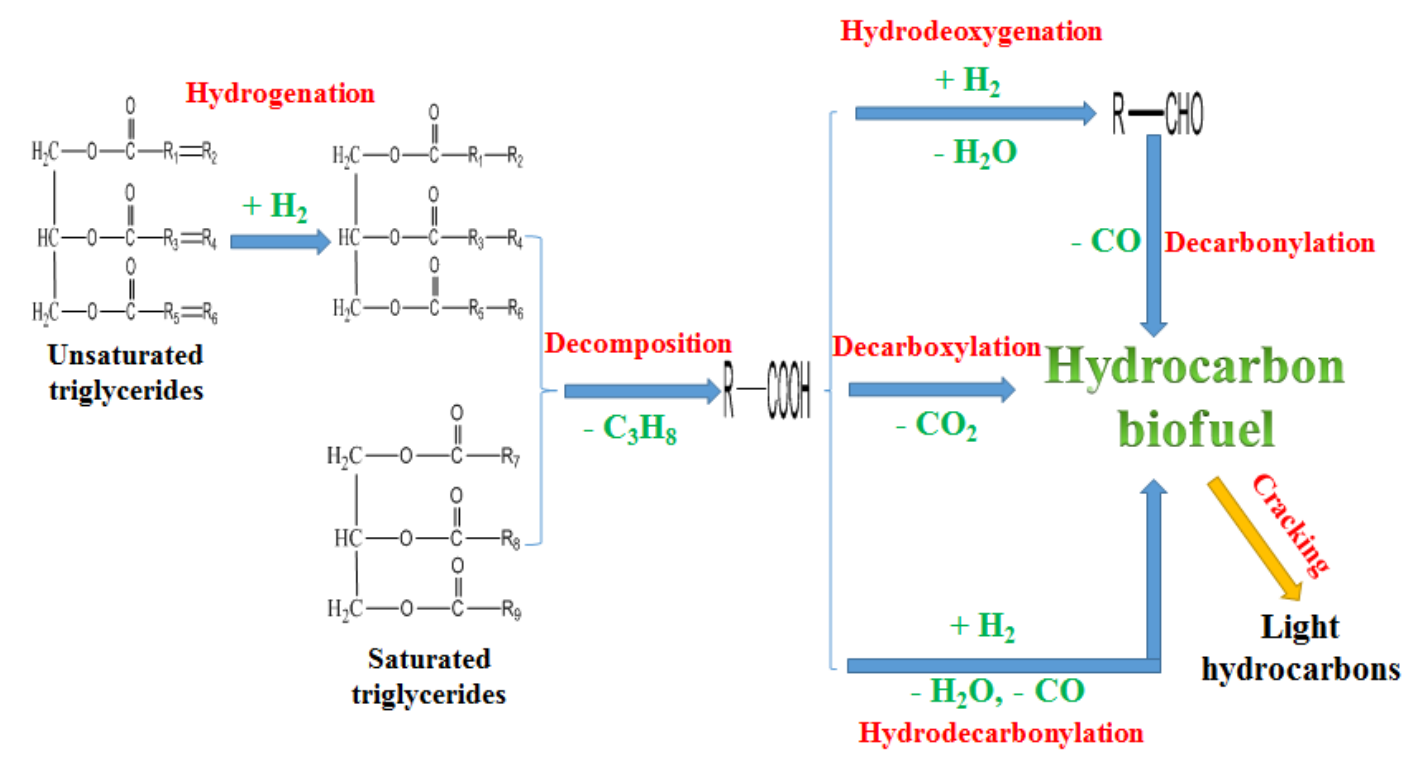

Figure 2. A proposed reaction pathway in the hydroprocessing of vegetable oil to hydrocarbon biofuel.

\subsection{Hydrocarbon Biofuel Properties}

Table 7 shows the typical properties of hydrocarbon biofuel. Biofuel is appropriate for ground transportation use [63]. The water content of hydrocarbon biofuel was low, which is the same to the water content of heavy fuel oil [19]. The $\mathrm{H} / \mathrm{C}$ molar ratio of hydrocarbon biofuel was between 1.73 and 2.03. The oxygen content of hydrocarbon biofuel was between 0 and $4.15 \mathrm{wt} \%$. The oxygen content of heavy fuel oil was $0.60-0.65 \mathrm{wt} \%$ [19]. Removing oxygen atoms can raise the combustion heat of hydrocarbon biofuel [11]. The nitrogen content of hydrocarbon biofuel was low and there was nearly no sulfur found in the hydrocarbon biofuel. It is significant to reduce sulfur forimproving air quality [12]. The acid number of hydrocarbon biofuel was $33.3 \mathrm{mg} \mathrm{KOH} / \mathrm{g}$, which was much lower than the acid number of the fuel $(300 \mathrm{mg} \mathrm{KOH} / \mathrm{g}$ ) derived from the bio-oil upgrading [30]. The viscosity of hydrocarbon biofuel $(1.45-4.22 \mathrm{cP})$ was lower than the viscosity of vegetable oil. This was due to the hydrocarbon biofuel containing high levels of hydrocarbons. The density of hydrocarbon biofuel $(0.76-0.88 \mathrm{~g} / \mathrm{mL})$ was generally lower than the density of vegetable oils $(0.84-0.93 \mathrm{~g} / \mathrm{mL})$ due to the 
removal of some oxygen atoms. The higher heating value of hydrocarbon biofuel (41.4-46.4 MJ/kg) was higher than that of vegetable oils (37.1-40.6 MJ $/ \mathrm{kg}$ ) due to the removal of oxygen atoms and production of hydrocarbons. The freezing point and flash point of hydrocarbon biofuel was $5^{\circ} \mathrm{C}$ and $120-138^{\circ} \mathrm{C}$, respectively. The cloud point of hydrocarbon biofuel ranged from $-5{ }^{\circ} \mathrm{C}$ to $30^{\circ} \mathrm{C}$. The fire point and pour point of hydrocarbon biofuel was $145^{\circ} \mathrm{C}$ and $9{ }^{\circ} \mathrm{C}$, respectively. The cetane number of hydrocarbon biofuel was 70-90. Table 8 shows the main composition of biofuels produced from the vegetable oil upgrading. In our previous study involving hydroprocessing of carinata oil over $\mathrm{Mo}-\mathrm{Zn} / \mathrm{Al}_{2} \mathrm{O}_{3}$ catalyst, the $\mathrm{C} 8-\mathrm{C} 18$ hydrocarbons had a high selectivity $(65 \%)$ to the hydrocarbon biofuel produced [31]. Yigezu and Muthukumar [76] reported the biofuel production through the catalytic cracking of sunflower oil over the vanadium pentoxide catalyst at $380^{\circ} \mathrm{C}$. The organic liquid product was separated into three main components based on the distillation temperature: gasoline $\left(80-140{ }^{\circ} \mathrm{C}\right)$, kerosene $\left(140-200^{\circ} \mathrm{C}\right)$, and heavy diesel $\left(\geq 200^{\circ} \mathrm{C}\right)$. The catalyst selectivity of the heavy diesel to organic liquid product was the highest, 56\%. Asikin-Mijan et al. [100] investigated the green diesel production via catalytic deoxygenation of Jatropha curcas oil over the Ni-Co/MWCNT catalyst. The selectivity of the C8-C17 hydrocarbons to the hydrocarbon biofuel produced was $53 \%-64 \%$, based on varying the $\mathrm{Ni}$ concentration from $5 \mathrm{wt} \%$ to $40 \mathrm{wt} \%$. Hydrocarbon biofuel should possess some characteristics including high thermal stability, high flash point, high energy density, low freezing point, low toxicity, lubricity, immiscibility in water and cold weather operability for the safe operation of current fuel systems $[12,63]$. Some of the hydrocarbon biofuels derived from vegetable oil upgrading cannot meet the property requirement of transportation liquid fuel. Therefore, these hydrocarbon biofuels need to be further refined using techniques such as distillation and isomerization.

Table 7. Typical properties of hydrocarbon biofuel.

\begin{tabular}{ccc}
\hline Characteristics & Hydrocarbon Biofuel & Ref. \\
\hline Water content $(\mathrm{wt} \%)$ & 0.10 & {$[32]$} \\
Carbon $(\mathrm{wt} \%)$ & $82.8-85.5$ & {$[57,65]$} \\
Hydrogen $(\mathrm{wt} \%)$ & $12.3-14.0$ & {$[57,65]$} \\
Oxygen $(\mathrm{wt} \%)$ & $0-4.15$ & {$[57,65,89]$} \\
Nitrogen $(\mathrm{wt} \%)$ & $0-0.75$ & {$[57,65]$} \\
Sulfur $(\mathrm{wt} \%)$ & $<$ detection limit & {$[57]$} \\
Acid number $(\mathrm{mg} \mathrm{KOH} / \mathrm{g})$ & 33.3 & {$[32]$} \\
Viscosity $(\mathrm{cP})$ & $1.45-4.22$ & {$[36,57,90]$} \\
Density $(\mathrm{g} / \mathrm{mL})$ & $0.76-0.88$ & {$[36,65,76,89,90,96]$} \\
HHV $(\mathrm{MJ} / \mathrm{kg})$ & $41.4-46.4$ & {$[96,89,90,96]$} \\
Freezing point $\left({ }^{\circ} \mathrm{C}\right)$ & 5 & {$[89]$} \\
Cloud point $\left({ }^{\circ} \mathrm{C}\right)$ & $-5-30$ & {$[57]$} \\
Pour point $\left({ }^{\circ} \mathrm{C}\right)$ & 9 & {$[57]$} \\
Fire point $\left({ }^{\circ} \mathrm{C}\right)$ & 145 & {$[57,96]$} \\
Flash point $\left({ }^{\circ} \mathrm{C}\right)$ & $120-138$ & {$[89]$} \\
Cetane number & $70-90$ &
\end{tabular}

Table 8. The main composition of biofuel produced from vegetable oil upgrading.

\begin{tabular}{cccc}
\hline Product & Main Composition & Selectivity (\%) & Ref. \\
\hline Hydrocarbon biofuel & C8-C12 hydrocarbons & 18 & {$[31]$} \\
Hydrocarbon biofuel & C12-C18 hydrocarbons & 47 & {$[31]$} \\
Organic liquid product & Gasoline & $\sim 20$ & {$[76]$} \\
Organic liquid product & Kerosine & $\sim 5$ & {$[76]$} \\
Organic liquid product & Heavy diesel & 56 & {$[76]$} \\
Organic liquid product & Gasoline & 44 & {$[1]$} \\
Organic liquid product & Kerosine & 17 & {$[9]$} \\
Organic liquid product & Diesel & 39 & {$[9]$} \\
Organic liquid product & Gasoline & $63-68$ & {$[9]$} \\
Product & Gasoline & $2-9$ & {$[25]$} \\
Product & $\geq$ C12 hydrocarbons & $78-85$ & {$[25]$} \\
Organic liquid product & Monocyclic aromatic hydrocarbons & $53-64$ & {$[77]$} \\
Hydrocarbon biofuel & C8-C17 hydrocarbons & & {$[100]$} \\
\hline
\end{tabular}




\subsection{Catalyst Properties}

Table 9 shows some typical properties of catalysts for vegetable oil upgrading process. The surface area, pore volume and acidity are the factors that have the most effect on the catalyst behavior. Zeolite based catalysts and $\mathrm{Al}_{2} \mathrm{O}_{3}$ based catalysts are main catalysts used to upgrade vegetable oil for hydrocarbon biofuel production. Some other catalysts including $\mathrm{Pd} / \mathrm{C}$ and $\mathrm{Mg} / \mathrm{SiO}_{2}$ have been used for vegetable oil upgrading. The supports of $\mathrm{ZSM}-5, \mathrm{Al}_{2} \mathrm{O}_{3}, \mathrm{ZrO}_{2}, \mathrm{SiO}_{2}$ and activated carbon are an important part of catalysts for vegetable oil upgrading. The BET surface area of zeolite based catalysts varied from $56 \mathrm{~m}^{2} / \mathrm{g}$ to $1126 \mathrm{~m}^{2} / \mathrm{g}$. Various metal elements such as $\mathrm{Zn}, \mathrm{Ni}$ and Mo were used to modify the activity of zeolites [101]. Taufiqurrahmi et al. [9] investigated the cracking of used palm oil over nanocrystalline zeolite beta and nanocrystalline zeolite Y. Compared to microcrystalline zeolites, the nanocrystalline zeolites had a higher surface area $\left(525 \mathrm{~m}^{2} / \mathrm{g}\right.$ for nanocrystalline zeolite beta and $1126 \mathrm{~m}^{2} / \mathrm{g}$ for nanocrystalline zeolite $\mathrm{Y}$, respectively) and exhibited a higher conversion of used palm oil. Zarchin et al. [22] studied the hydroprocessing of soybean oil over $\mathrm{Ni}_{2} \mathrm{P} / \mathrm{HY}$ catalyst. The water vapors generated by hydrodeoxygenation reaction reduced the acidity of the $\mathrm{Ni}_{2} \mathrm{P} / \mathrm{HY}$ catalyst, thus reducing the hydrocracking activity. Ishihara et al. [25] investigated the catalytic cracking of soybean oil over hierarchical zeolite containing mesoporous silica-aluminas. Not only the acid site but also the pore size $(20 \AA)$ of the zeolite $\beta$ catalyst was important for obtaining high gasoline yield during the soybean oil upgrading. A high acid site of a zeolite may not be effective if the crystal size is large since the soybean oil molecules may not approach the acid site. Fan et al. [27] studied the hydrocracking of Jatropha oil over $\mathrm{Ni}-\mathrm{H}_{3} \mathrm{PW}_{12} \mathrm{O}_{40}$ catalyst and found that the interaction between $\mathrm{Ni}$ and $\mathrm{H}_{3} \mathrm{PW}_{12} \mathrm{O}_{40}$ could increase the acid sites. Wang and $\mathrm{Yu}$ [43] studied the hydrocarbon fuel production from the catalytic cracking of rubber seed oil over the mesoporous molecular sieve (MNC-13) catalyst. The Lewis acid and Brønsted acid sites coexisted on the surface of the MNC-13 catalyst. The relative intensity of Brønsted acid to Lewis acid of the MNC-13 catalyst was 0.9 . The results indicate that the Lewis acid site plays a key role in the catalyst activity towards the liquid product yield.

Lovás et al. [50] studied the catalytic cracking of rapeseed oil over the fluid catalytic cracking ZSM-5 catalyst. The overall catalytic performance is related to the catalyst acidity, surface area and structure accessibility. A high acidity of the fluid catalytic cracking ZSM-5 catalyst could improve the cracking of olefin intermediates. Yenumala et al. [57] investigated the hydrodeoxygenation of karanja oil over $\mathrm{Ni} / \mathrm{ZSM}-5$ catalyst. The $\mathrm{SiO}_{2}$ was almost neutral, the $\mathrm{Al}_{2} \mathrm{O}_{3}$ was weakly acidic, and the HZSM-5 $\left(0.55 \mathrm{mmol}\right.$ of $\left.\mathrm{NH}_{3} \cdot \mathrm{g}^{-1}\right)$ was strongly acidic. The good catalytic activity of the Ni/ZSM- 5 catalyst may result from its high surface area and strong acidity $\left(0.27 \mathrm{mmol}\right.$ of $\left.\mathrm{NH}_{3} \cdot \mathrm{g}^{-1}\right)$. Twaiq et al. [74] studied the catalytic conversion of palm oil over various zeolites. The product distribution was found to be different due to the change in the pore size of the different catalysts. A low acidity of the catalyst favored the coke formation on the catalyst surface. Wu et al. [77] studied jet fuel production from catalytic transformation of triglyceride based oils over zeolites. Compared to HZSM-5 (0.27 mmol of $\left.\mathrm{NH}_{3} \cdot \mathrm{g}^{-1}\right)$, the $\mathrm{HY}$ catalyst had a higher acidity $\left(1.71 \mathrm{mmol}\right.$ of $\left.\mathrm{NH}_{3} \cdot \mathrm{g}^{-1}\right)$, producing more polycyclic aromatic hydrocarbons, coke and tar. Wang et al. [102] investigated the hydrotreating of soybean oil over NiMo carbide catalysts. The $\mathrm{NiMoC} / \mathrm{Al}_{2} \mathrm{O}_{3}$ catalyst had the highest surface area $\left(712 \mathrm{~m}^{2} / \mathrm{g}\right)$ and the highest yield of organic liquid product. Pore structure of the catalyst plays a significant role in controlling the diesel selectivity. A larger pore structure could cause less secondary cracking of heavy hydrocarbons, thus resulting in a higher diesel selectivity. Abbasov et al. [103] studied catalytic cracking of vegetable oils over halloysite nanotubes for biofuel production. Large molecules in vegetable oil are difficult to deeply penetrate the small pores (smaller than 1-2 nm) of catalysts, thus limiting the cracking efficiency of the reaction sites on the catalyst surface. Zeolite based catalysts possess robust catalytic cracking capabilities through reactions of dehydration, decarbonylation and decarboxylation [104].

The $\mathrm{Al}_{2} \mathrm{O}_{3}$ based catalysts have a high BET surface area ranging between $148 \mathrm{~m}^{2} / \mathrm{g}$ and $358 \mathrm{~m}^{2} / \mathrm{g}$. Compared to pure $\mathrm{Al}_{2} \mathrm{O}_{3}$, the surface area of modified $\mathrm{Al}_{2} \mathrm{O}_{3}$ decreased due to the doping of some metals such as $\mathrm{Co}, \mathrm{Ni}, \mathrm{Pd}, \mathrm{Pt}$ and $\mathrm{Mg}$. The noble metal catalysts (e.g., $\mathrm{Pt}, \mathrm{Pd}$ ) could activate $\mathrm{H}_{2}$ 
and increase catalyst lifetime due to being less susceptible to deactivation [71]. The pore volume of zeolite based catalysts was between $0.10 \mathrm{~cm}^{3} / \mathrm{g}$ and $1.34 \mathrm{~cm}^{3} / \mathrm{g}$. The properties of these catalysts vary significantly. The pore volume of $\mathrm{Al}_{2} \mathrm{O}_{3}$ based catalysts was between $0.18 \mathrm{~cm}^{3} / \mathrm{g}$ and $1.1 \mathrm{~cm}^{3} / \mathrm{g}$. The metal modified $\mathrm{Al}_{2} \mathrm{O}_{3}$ catalysts had a lower pore volume than the pore volume of pure $\mathrm{Al}_{2} \mathrm{O}_{3}$ since the introduction of metals may cause partial blockage of the catalyst channels [105]. Ni is usually used as a promoter to increase the activity of Mo in a traditional catalyst [72]. The pore size of zeolite based catalysts varied from $3 \AA$ to $64 \AA$. The medium pore size catalysts were found to be efficient in the cracking process [74]. The pore size of $\mathrm{Al}_{2} \mathrm{O}_{3}$ based catalysts was between $32 \AA$ and $90 \AA$. Catalyst support plays a significant role in dispersing active phases of catalysts and the $\mathrm{Al}_{2} \mathrm{O}_{3}$ support could partially transform into $\mathrm{AlO}(\mathrm{OH})$ in the presence of $\mathrm{H}_{2} \mathrm{O}$ [106]. Bruce et al. [93] investigated the thermocatalytic cracking kinetics of myristic acid over various catalysts. Compared to HZSM- 5 $\left(0.56 \mathrm{mmol}\right.$ of $\left.\mathrm{NH}_{3} \cdot \mathrm{g}^{-1}\right)$, the silica-alumina catalyst $\left(0.27 \mathrm{mmol}\right.$ of $\left.\mathrm{NH}_{3} \cdot \mathrm{g}^{-1}\right)$ had lower acidity which favors the short-chain hydrocarbon production.

The pore size of other catalysts ranged from $20 \AA$ to $297 \AA$. Product selectivity is related to the pore size of catalysts and takes place when parts of products inside the catalyst pores are too large to diffuse out. These large molecules are either transformed to smaller ones or blocking the catalyst pores. The catalyst pores need to have a defined structure for product selectivity [73].Hwang et al. [107] studied the biofuel production from Jatropha oil over Pd/C catalysts. During the catalytic reaction of crude vegetable oils, catalyst deactivated by the accumulation, adsorption and blocking of reactants and products. Asikin-Mijan et al. [100] investigated the catalytic deoxygenation of Jatropha curcas oil for green diesel production. The Ni-Co/MWCNT catalyst having a high surface area $\left(109 \mathrm{~m}^{2} / \mathrm{g}\right)$ with large pore volume $\left(1.27 \mathrm{~cm}^{3} / \mathrm{g}\right)$ and pore size $(172 \AA)$ was suitable for large vegetable oil molecule reaction. In addition, the Ni-Co/MWCNT catalyst had a high acid site (about $0.76 \mathrm{mmol} / \mathrm{g}$ ), which favored the pathway of decarboxylation and decarbonylation in the deoxygenation process. The acid site of zeolite based catalysts was between $0.27 \mathrm{mmol} / \mathrm{g}$ and $4.55 \mathrm{mmol} / \mathrm{g}$, which was higher than the acid site of $\mathrm{Al}_{2} \mathrm{O}_{3}$ based catalysts $(0.14-0.27 \mathrm{mmol} / \mathrm{g})$. Zeolites contain Lewis acid sites and Brønsted acid sites. The product selectivity during vegetable oil upgrading can be controlled using acid sites' density distribution and strength [73]. Acid sites can be classified as strong acid sites, medium acid sites and weak acid sites. A high total acid site is critical for the vegetable oil upgrading to hydrocarbon biofuel [20]. During the vegetable oil upgrading process, the activity and selectivity of catalysts were affected by factors including acid site and pore size [74]. The cost of catalysts is a significant expense, but utilizing catalysts derived from waste materials could enhance the reaction process by reducing cost and improving environment friendliness. Red mud is a solid waste formed during the production of alumina from the digestion of bauxite. Red mud catalyst has high pore size and has been used for the transesterification of vegetable oils including soybean oil and Mahua oil. Red mud catalyst exhibits a high activity towards the transesterification of vegetable oils [108-110]. The properties of catalysts can be improved under proper conditions, but the commercialization of catalysts is still a challenge due to their large property difference.

Table 9. The properties of catalysts used in vegetable oil upgrading to biofuel.

\begin{tabular}{|c|c|c|c|c|c|}
\hline Catalyst & $\begin{array}{l}\text { BET Surface } \\
\text { Area }\left(\mathrm{m}^{2} / \mathrm{g}\right)\end{array}$ & $\begin{array}{l}\text { Pore Volume } \\
\quad\left(\mathrm{cm}^{3} / \mathrm{g}\right)\end{array}$ & Pore Size $(\AA ̊)$ & $\begin{array}{c}\text { Acid Sites } \\
(\mathrm{mmol} / \mathrm{g})\end{array}$ & Ref. \\
\hline HZSM-5 & $282-358$ & $0.20-0.23$ & - & $0.27-0.58$ & [77] \\
\hline K/HZSM-5 & 387 & 0.16 & - & - & [74] \\
\hline $\mathrm{Zn} / \mathrm{HZSM}-5$ & 172 & 0.25 & 57 & - & [21] \\
\hline Zn/Na-ZSM-5 & 73 & 0.12 & 64 & - & {$[32,90]$} \\
\hline NiMoC/ZSM-5 & 447 & 0.13 & 55 & - & {$[92,102]$} \\
\hline NiMoN/ZSM-5 & 299 & 0.11 & 56 & - & [92] \\
\hline $\mathrm{Ni} / Z \mathrm{SM}-5$ & $386-451$ & $0.36-0.44$ & 39 & 0.27 & {$[57,111,112]$} \\
\hline Fe-Zn-Cu-ZSM-5 & $244-295$ & $0.16-0.18$ & $25-27$ & - & [1] \\
\hline Fe-Zn-ZSM-5 & 209 & 0.13 & 25 & - & {$[1]$} \\
\hline NiW/HZSM-5 & 253 & 0.20 & - & - & [113] \\
\hline $\mathrm{MoO}_{3} / \mathrm{HZSM}-5$ & $303-323$ & - & - & $0.48-0.51$ & [105] \\
\hline
\end{tabular}


Table 9. Cont.

\begin{tabular}{|c|c|c|c|c|c|}
\hline Catalyst & $\begin{array}{l}\text { BET Surface } \\
\text { Area }\left(\mathrm{m}^{2} / \mathrm{g}\right)\end{array}$ & $\begin{array}{l}\text { Pore Volume } \\
\left(\mathrm{cm}^{3} / \mathrm{g}\right)\end{array}$ & Pore Size $(\AA)$ & $\begin{array}{l}\text { Acid Sites } \\
(\mathrm{mmol} / \mathrm{g})\end{array}$ & Ref. \\
\hline Fluid catalytic cracking ZSM-5 & 56 & 0.11 & - & - & [50] \\
\hline Zeolite $\beta$ & 627 & 0.32 & 20 & - & [25] \\
\hline Zeolite HY5.5 & 725 & 0.41 & 23 & - & [25] \\
\hline Zeolite USY & 554 & 0.23 & 25 & - & [114] \\
\hline HY zeolite & 250 & 0.21 & - & - & [113] \\
\hline Nanocrystalline zeolite $Y$ & 1126 & 1.34 & 5 & 0.70 & [9] \\
\hline Nanocrystalline zeolite beta & 525 & 0.54 & 3 & 0.42 & [9] \\
\hline $\mathrm{HY}$ & 620 & 0.40 & - & 1.71 & [77] \\
\hline $\mathrm{Ni}_{2} \mathrm{P} / \mathrm{HY}$ & 482 & 0.24 & 38 & - & [22] \\
\hline $\mathrm{NiW} / \mathrm{HY}$ & 222 & 0.12 & - & - & [113] \\
\hline Omnikat & 200 & 0.40 & $<30$ & 0.53 & [103] \\
\hline MNC-13 & - & - & - & 1.16 & [43] \\
\hline HMCM-41 & 925 & 0.73 & - & 0.99 & [77] \\
\hline $\mathrm{Ni} / \mathrm{SAPO}-11$ & $169-224$ & $0.10-0.14$ & $20-23$ & - & [115] \\
\hline $\mathrm{Ni} /$ Mesoporous-Y & 518 & - & 39 & 4.55 & [94] \\
\hline $\mathrm{Ni} /$ Mesoporous-Hbeta & 368 & - & 37 & 2.58 & [94] \\
\hline Ni/Mesoporous-HZSM-5 & 321 & - & 28 & 1.55 & [94] \\
\hline $\mathrm{Al}_{2} \mathrm{O}_{3}$ & 298 & 1.1 & 61 & 0.23 & {$[27,93]$} \\
\hline $\mathrm{Co} / \mathrm{Al}_{2} \mathrm{O}_{3}$ & $171-187$ & $0.47-0.50$ & 75 & - & [116] \\
\hline $\mathrm{Ni} / \mathrm{Al}_{2} \mathrm{O}_{3}$ & $148-222$ & $0.48-0.63$ & 75 & $0.14-0.21$ & {$[57,116]$} \\
\hline $\mathrm{Pd} / \mathrm{Al}_{2} \mathrm{O}_{3}$ & $194-214$ & $0.50-0.58$ & 75 & - & [116] \\
\hline $\mathrm{Pt} / \mathrm{Al}_{2} \mathrm{O}_{3}$ & $196-217$ & $0.51-0.58$ & 75 & - & [116] \\
\hline $\mathrm{Mg} / \mathrm{Al}_{2} \mathrm{O}_{3}$ & 175 & 0.39 & 90 & - & [117] \\
\hline $\mathrm{SiO}_{2} / \mathrm{Al}_{2} \mathrm{O}_{3}$ & - & - & - & 0.27 & [93] \\
\hline $\mathrm{NiMoC} / \mathrm{Al}_{2} \mathrm{O}_{3}$ & 216 & 0.21 & - & - & [102] \\
\hline $\mathrm{Mo}-\mathrm{Zn} / \mathrm{Al}_{2} \mathrm{O}_{3}$ & $214-358$ & $0.18-0.28$ & $32-33$ & - & [31] \\
\hline $\mathrm{Pd} / \mathrm{C}$ & 690 & 0.68 & 39 & - & [107] \\
\hline $\mathrm{Mg} / \mathrm{SiO}_{2}$ & 186 & 0.14 & 29 & - & [117] \\
\hline $\mathrm{Mg} / \mathrm{ZrO}_{2}$ & 6 & 0.04 & 238 & - & [117] \\
\hline $\mathrm{Ni}_{2} \mathrm{P} /$ silica & 203 & 0.66 & 97 & - & [22] \\
\hline $\mathrm{Ni}-\mathrm{Ce} / \mathrm{TiO}_{2}$ & 44 & 0.37 & 297 & - & [118] \\
\hline $\mathrm{Ni}-\mathrm{Ce} / \mathrm{TNS}$ & 16 & 0.08 & 170 & - & [118] \\
\hline $\mathrm{Ni}-\mathrm{Ce} / \mathrm{TNT}$ & 157 & 0.44 & 111 & - & [118] \\
\hline Co/MWCNT & 111 & 1.05 & 153 & 7.37 & [100] \\
\hline $\mathrm{Ni} / \mathrm{MWCNT}$ & 42 & 0.42 & 154 & $2.17-4.34$ & [100] \\
\hline Halloysite nanotube & 26 & 0.08 & $20-100$ & 0.15 & [103] \\
\hline $\mathrm{Mg} / \mathrm{AC}$ (active carbon) & 549 & 0.44 & 32 & - & [117] \\
\hline Red mud & $11-23$ & $0.01-0.09$ & $142-223$ & - & [108] \\
\hline
\end{tabular}

Table 10 shows some typical properties of catalysts used in bio-oil upgrading process. Zeolite based catalysts (such as HZSM-5, La/HZSM-5, Mo/HZSM-5, Cu/HZSM-5, $\beta$-zeolite and H-mordenite) and $\mathrm{Al}_{2} \mathrm{O}_{3}$ based catalysts (such as $\mathrm{Na}_{2} \mathrm{CO}_{3} / \mathrm{Al}_{2} \mathrm{O}_{3}, \mathrm{Zn} / \mathrm{Al}_{2} \mathrm{O}_{3}, \mathrm{Ce} / \mathrm{Al}_{2} \mathrm{O}_{3}, \mathrm{Ni}-\mathrm{Ce} / \mathrm{Al}_{2} \mathrm{O}_{3}, \mathrm{Pt} / \mathrm{Al}_{2} \mathrm{O}_{3}$, $\mathrm{Co}-\mathrm{Mo} / \mathrm{Al}_{2} \mathrm{O}_{3}$ and $\mathrm{CoP} / \mathrm{Al}_{2} \mathrm{O}_{3}$ ) are usually used to upgrade bio-oil for hydrocarbon biofuel production $[8,19]$. HZSM-5 is an effective catalyst to upgrade bio-oil to hydrocarbons, organic distillates and aromatics [8]. Fluid catalytic cracking is one important process used in petroleum refinery and is applied to convert crude oil to high value products. Coked fluid catalytic cracking catalysts are periodically burned off in the petroleum field to provide heat for the process and regenerate catalysts [119]. Mesoporous zeolites such as MFI, Y and beta exhibit high surface area and have been recently used for the upgrading of bio-oil. The mesoporous materials could promote the diffusion of reactants into the meso-pores [120,121]. Wei et al. [122] studied the hydrocarbon production from upgrading rich phenolic compound bio-oil over zeolites. The acid sites of catalysts can donate protons to form hydrocarbon cation. The coke generated via polymerization can reduce both size and area of micropore on ZSM-5. The coke can cause a barrier for guaiacol diffusion, thus blocking the pores of ZSM-5. Lee et al. [123] investigated the catalytic hydrodeoxygenation of bio-oil model compounds over zeolite catalysts. The cyclohexane yield increased with the increase of acid sites on the $\mathrm{Pt} / \mathrm{HY}$ catalyst. Compared to Pt/HZSM-5 catalyst, the Pt/HY catalyst had a larger pore size and was expected to improve the guaiacol diffusion toward the acid sites inside the catalyst. Huynh et al. [124] investigated the upgrading of bio-oil under various catalysts. The low degree of deoxygenation value over the $\mathrm{NiCo} / \mathrm{ZrO}_{2}$ catalyst can be attributed to its lower surface area $\left(40 \mathrm{~mm}^{2} / \mathrm{g}\right)$ and acidity $(0.04 \mathrm{mmol} / \mathrm{g})$ compared to other catalysts including NiCo/HBeta, NiCo/HY and NiCo/HZSM-5. 
The Brønsted acid site concentrations of the catalyst supports followed the order of HY > HZSM-5 > $\mathrm{HBeta}>\mathrm{ZrO}_{2}$. Karnjanakom et al. [125] studied the catalytic upgrading of bio-oil over $\mathrm{Cu} / \mathrm{KIT}-6$ and $\mathrm{Cu} / \mathrm{MCM}-41$ catalysts. A higher acidity of the catalyst favored the conversion of oxygenates in the bio-oil to hydrocarbons through the deoxygenation reaction. Jang et al. [126] investigated the catalytic upgrading of bio-oil model compound over mesoporous solid catalysts. They found the introduction of aluminum to the support (e.g., silica and SBA-15) could generate weak acid sites. Gamliel et al. [127] studied the catalytic fast pyrolysis of biomass (e.g., cellulose and miscanthus) with tailored mesoporous MFI zeolites. The mesoporous MFI zeolites had a surface area of $342-484 \mathrm{~m}^{2} / \mathrm{g}$, pore volume of $0.25-0.53 \mathrm{~cm}^{3} / \mathrm{g}$, and Brønsted acid site of $0.29-0.55 \mathrm{mmol} / \mathrm{g}$. The mesoporous MFI zeolites were effective at improving the bio-oil yield from catalytic fast pyrolysis of biomass. The carbon balance for catalytic fast pyrolysis of cellulose was $97 \%-103 \%$. Foster et al. [128] investigated the catalytic fast pyrolysis of biomass (e.g., glucose and maple wood) over mesoporous and non-mesoporous ZSM-5 catalysts. Incorporating hierarchical mesopores within the zeolite was helpful to increase the production of larger alkylated monoaromatics.

Commercial catalysts commonly used for the hydroprocessing of bio-oil are sulfide $\mathrm{Co}-\mathrm{Mo} / \mathrm{Al}_{2} \mathrm{O}_{3}$ and $\mathrm{Ni}-\mathrm{Mo} / \mathrm{Al}_{2} \mathrm{O}_{3}$ catalysts. After being sulfided appropriately, the catalysts are thermally stable without rapid coking $[71,99]$. During the upgrading of bio-oil, other types of catalysts have been investigated including $\mathrm{ZrO}_{2} / \mathrm{TiO}_{2}, \mathrm{MgO}, \mathrm{CaO}, \mathrm{Ni} / \mathrm{W} / \mathrm{TiO}_{2}, \mathrm{Pd} / \mathrm{C}, \mathrm{Fe} / \mathrm{C}, \mathrm{Pt} / \mathrm{SiO}_{2}$, etc. [19]. Red mud catalyst has also been used for the upgrading of bio-oil. Red mud is a mixture of metal oxides including $\mathrm{Al}_{2} \mathrm{O}_{3}, \mathrm{SiO}_{2}$ and $\mathrm{Fe}_{2} \mathrm{O}_{3}$ [109]. The catalyst type and operation conditions have an influence on the production distributions of bio-oil upgrading [8]. The BET surface area of zeolite based catalysts varied from $122 \mathrm{~m}^{2} / \mathrm{g}$ to $1020 \mathrm{~m}^{2} / \mathrm{g}$. The pore size of zeolite based catalysts varied from $20 \AA$ to $117 \AA$. The ZSM-5 catalyst has high acidity and shape selectivity, but it has low biofuel yield and short lifetime during the bio-oil upgrading process [119]. Multifunctional catalysts (e.g., zeolites with doping $\mathrm{Zn}, \mathrm{Cu}, \mathrm{Ni}$ and $\mathrm{Mo}$ ) are needed for both bio-oil upgrading and vegetable oil upgrading. Sintering of the metal particles could reduce the active surface area of the catalysts. Tuning the catalyst composition through modification of the metal formulation and/or the support material surface could mitigate particle sintering. Nobel metal catalysts have a high hydroprocessing activity, but the application on large scale is hampered by their high cost [71]. The $\mathrm{Al}_{2} \mathrm{O}_{3}$ based catalysts have high BET surface area between $135 \mathrm{~m}^{2} / \mathrm{g}$ and $381 \mathrm{~m}^{2} / \mathrm{g} . \mathrm{Al}_{2} \mathrm{O}_{3}$ has been widely used in industrial bio-oil upgrading to remove sulfur from the crude oil [72]. Common metals such as $\mathrm{Co}, \mathrm{Mo}, \mathrm{Ni}$, and $\mathrm{Zn}$ are usually used to modify the activity of $\mathrm{Al}_{2} \mathrm{O}_{3}$. The instability of the $\mathrm{Al}_{2} \mathrm{O}_{3}$ support in a high water content environment is a shortcoming during the hydroprocessing of bio-oil [119]. Understanding the interplay between catalyst surface structure and reaction conditions is significant for the bio-oil upgrading [71]. The pore volume of zeolite based catalysts was between $0.12 \mathrm{~cm}^{3} / \mathrm{g}$ and $1.1 \mathrm{~cm}^{3} / \mathrm{g}$; and the pore volume of $\mathrm{Al}_{2} \mathrm{O}_{3}$ based catalysts was between $0.08 \mathrm{~cm}^{3} / \mathrm{g}$ and $0.72 \mathrm{~cm}^{3} / \mathrm{g}$. The design of catalysts including composition, surface morphology and crystal phase could be modeled to assist synthesizing high activity catalysts [71]. The pore size of $\mathrm{Al}_{2} \mathrm{O}_{3}$ based catalysts was between $31 \AA$ and $90 \AA$. The pore size of other catalysts (e.g., $\mathrm{SiO}_{2}$ ) ranged from $32 \AA$ to $289 \AA$. The supports of $\mathrm{Al}_{2} \mathrm{O}_{3}$ and $\mathrm{SiO}_{2}$ have an influence on the product selectivity during the bio-oil upgrading. Support materials such as mesoporous zeolite, silica and activated carbon are more stable in acidic environment than conventional alumina [71]. The acid site of all catalysts was between $0.03 \mathrm{mmol} / \mathrm{g}$ and $1.12 \mathrm{mmol} / \mathrm{g}$. The acidic HZSM-5 catalyst usually causes coke formation through decarboxylation, decarbonylation, dealkylation, cracking and aromatization reactions [73]. Karnjanakom et al. [129] studied the bio-oil upgrading over metal-loaded $\mathrm{Al}_{2} \mathrm{O}_{3}$ catalysts. The large pore size $\left(90 \AA\right.$ ) of $\mathrm{Al}_{2} \mathrm{O}_{3}$ provided the potential for the diffusion of large bio-oil molecules and the reduction of coke formation. The surface area and pore size of the metal-loaded $\mathrm{Al}_{2} \mathrm{O}_{3}$ catalysts decreased with a higher metal loading. Karnjanakom et al. [130] investigated the catalytic upgrading of bio-oil to hydrocarbons over metal-doped $\mathrm{Al}_{2} \mathrm{O}_{3}$ catalysts. The acidity of $\mathrm{Zn} / \mathrm{Al}_{2} \mathrm{O}_{3}$ catalysts 
increased from $0.29 \mathrm{mmol} / \mathrm{g}$ to $0.33 \mathrm{mmol} / \mathrm{g}$ with the increase of $\mathrm{Zn}$ loading from $1.0 \mathrm{wt} \%$ to $2.5 \mathrm{wt} \%$. The loading of metal on $\mathrm{Al}_{2} \mathrm{O}_{3}$ could promote the electron pair acceptors or Lewis acid sites.

Activated carbon is considered to be a promising support for the hydroprocessing of bio-oil due to its textural properties and thermal stability. The carbon support has a low catalyst deactivation due to its neutral nature. Similar to carbon, the $\mathrm{SiO}_{2}$ support is often used for hydroprocessing of bio-oil due to its inert character. $\mathrm{ZrO}_{2}$ and $\mathrm{MgO}$ are good basic supports for the hydroprocessing of bio-oil. $\mathrm{ZrO}_{2}$ is highly coke resistant due to its low acidic and lower affinity towards water [72]. The activity of the catalyst formulation is affected by many parameters including $\mathrm{pH}$, time, temperature, cations and anions. The presence of non-metal such as $\mathrm{P}$ and $\mathrm{C}$ on the catalyst surface could create different sites for reaction and adsorption. $\mathrm{Ni}_{2} \mathrm{P}$ was reported as a promising catalyst for bio-oil upgrading due to its good stability, high activity and superior selectivity. The acidity of the support materials such as HZSM-5 and $\mathrm{Al}_{2} \mathrm{O}_{3}$ affects the adsorption properties [71]. Oh et al. [131] investigated the bio-oil upgrading over noble metal catalysts of $\mathrm{Ru} / \mathrm{C}$ and $\mathrm{Pt} / \mathrm{C}$. The surface area, pore size, and pore volume of these two catalysts all decreased after three times of reusing. The optimization of metal and supports is important for obtaining catalysts that are economically and technically feasible [72].

Table 10. The properties of catalysts used in bio-oil upgrading to biofuel.

\begin{tabular}{|c|c|c|c|c|c|}
\hline Catalyst & $\begin{array}{l}\text { BET Surface } \\
\text { Area }\left(\mathrm{m}^{2} / \mathrm{g}\right)\end{array}$ & $\begin{array}{l}\text { Pore Volume } \\
\left(\mathrm{cm}^{3} / \mathrm{g}\right)\end{array}$ & Pore Size (Å) & $\begin{array}{c}\text { Acid Sites } \\
(\mathrm{mmol} / \mathrm{g})\end{array}$ & Ref. \\
\hline HZSM-5 & $416-430$ & $0.22-0.40$ & 25 & 0.17 & {$[122,132]$} \\
\hline Pt/HZSM-5 & 335 & 0.29 & - & - & [123] \\
\hline $\mathrm{Ni} / \mathrm{HZSM}-5$ & $227-290$ & $0.12-0.16$ & $20-22$ & 0.59 & {$[124,133,134]$} \\
\hline $\mathrm{Zn} / \mathrm{HZSM}-5$ & $287-414$ & $0.14-0.21$ & 25 & - & [132] \\
\hline Co/HZSM-5 & 518 & 0.58 & 42 & - & [101] \\
\hline Mo/HZSM-5 & 521 & 0.59 & 41 & - & [101] \\
\hline NiCo/HZSM-5 & 281 & - & - & 0.67 & [124] \\
\hline MoCo/HZSM-5 & $475-496$ & $0.51-0.57$ & $43-46$ & - & [101] \\
\hline FCC (fluid catalytic cracking) & 122 & 0.15 & 117 & 0.03 & [135] \\
\hline$\beta$-zeolite & 410 & 0.25 & 25 & 0.23 & [136] \\
\hline $\mathrm{Cu} / \beta$-zeolite & $477-520$ & $0.30-0.32$ & $24-25$ & $0.27-0.56$ & [136] \\
\hline $\mathrm{Pt} / \mathrm{HY}$ & $527-697$ & $0.33-0.50$ & - & - & [123] \\
\hline $\mathrm{NiCo} / \mathrm{HY}$ & 568 & - & - & 0.77 & [124] \\
\hline $\mathrm{NiCo} / \mathrm{HBeta}$ & 434 & - & - & 1.12 & [124] \\
\hline Mesoporous beta & 733 & - & 97 & - & [120] \\
\hline $\mathrm{Pt} /$ mesoporous $\mathrm{Y}$ & 663 & 0.5 & 30 & 0.61 & [121] \\
\hline $\mathrm{Pt} /$ mesoporous MFI & 509 & 0.5 & 38 & 0.70 & [121] \\
\hline MCM- 41 & 1020 & 0.97 & 23 & - & [125] \\
\hline $\mathrm{Cu} / \mathrm{MCM}-41$ & $384-779$ & $0.54-0.88$ & $20-23$ & $0.22-0.73$ & [125] \\
\hline SBA-15 & 767 & 1.1 & 72 & - & [126] \\
\hline $\mathrm{Al} / \mathrm{SBA}-15$ & 733 & 1.0 & 82 & - & [126] \\
\hline $\mathrm{Pt} / \mathrm{SBA}-15$ & 684 & 1.0 & 72 & - & [126] \\
\hline $\mathrm{NiMg} / \mathrm{SBA}-15$ & $251-368$ & $0.35-0.47$ & $38-43$ & - & [137] \\
\hline $\mathrm{PrSO}_{3} \mathrm{H} / \mathrm{SBA}-15$ & $619-675$ & $0.73-0.77$ & 51 & - & [138] \\
\hline KIT-6 & 712 & 0.9 & 72 & - & [126] \\
\hline $\mathrm{Al} / \mathrm{KIT}-6$ & 701 & 0.8 & 72 & - & [126] \\
\hline $\mathrm{Pt} / \mathrm{KIT}-6$ & 665 & 0.9 & 72 & - & [126] \\
\hline $\mathrm{Al}_{2} \mathrm{O}_{3}$ & 232 & 0.72 & 90 & 0.36 & [129] \\
\hline $\mathrm{Ni} / \mathrm{Al}_{2} \mathrm{O}_{3}$ & 376 & 0.44 & 31 & 0.36 & [130] \\
\hline $\mathrm{Zn} / \mathrm{Al}_{2} \mathrm{O}_{3}$ & 190 & 0.65 & 89 & 0.43 & [129] \\
\hline $\mathrm{Fe} / \mathrm{Al}_{2} \mathrm{O}_{3}$ & 189 & 0.60 & 82 & 0.37 & [129] \\
\hline $\mathrm{Co} / \mathrm{Al}_{2} \mathrm{O}_{3}$ & 202 & 0.69 & 74 & 0.36 & [129] \\
\hline $\mathrm{Ce} / \mathrm{Al}_{2} \mathrm{O}_{3}$ & 381 & 0.51 & 31 & 0.31 & [130] \\
\hline $\mathrm{CoP} / \mathrm{Al}_{2} \mathrm{O}_{3}$ & 147 & 0.17 & 38 & - & [139] \\
\hline $\mathrm{Ni}_{2} \mathrm{P} / \mathrm{Al}_{2} \mathrm{O}_{3}$ & 198 & 0.23 & 33 & - & [139] \\
\hline $\mathrm{NiMg} / \mathrm{Al}_{2} \mathrm{O}_{3}$ & $135-177$ & $0.08-0.32$ & $38-78$ & - & [137] \\
\hline $\mathrm{CoMo} / \mathrm{Al}_{2} \mathrm{O}_{3}$ & $176-219$ & $0.21-0.50$ & 39 & 1.0 & {$[140,141]$} \\
\hline $\mathrm{AC}$ & 731 & 0.92 & 51 & - & [106] \\
\hline $\mathrm{Ni} / \mathrm{AC}$ & 723 & 0.87 & 49 & - & [106] \\
\hline $\mathrm{NiFe} / \mathrm{AC}$ & 688 & 0.83 & 48 & - & [106] \\
\hline $\mathrm{NiCu} / \mathrm{AC}$ & 683 & 0.81 & 47 & - & [106] \\
\hline $\mathrm{NiMo} / \mathrm{AC}$ & 627 & 0.81 & 48 & - & [106] \\
\hline $\mathrm{Pt} / \mathrm{C}$ & 1179 & 1.06 & 47 & - & [131] \\
\hline $\mathrm{Ru} / \mathrm{C}$ & 667 & 0.66 & 62 & - & [131] \\
\hline $\mathrm{SiO}_{2}$ & 200 & 0.81 & 90 & 0.09 & [129] \\
\hline $\mathrm{Pt} / \mathrm{SiO}_{2}$ & 448 & 0.7 & 82 & - & [126] \\
\hline $\mathrm{Ni} / \mathrm{SiO}_{2}$ & 219 & 0.68 & - & - & [142] \\
\hline
\end{tabular}


Table 10. Cont.

\begin{tabular}{|c|c|c|c|c|c|}
\hline Catalyst & $\begin{array}{l}\text { BET Surface } \\
\text { Area }\left(\mathrm{m}^{2} / \mathrm{g}\right)\end{array}$ & $\begin{array}{l}\text { Pore Volume } \\
\left(\mathrm{cm}^{3} / \mathrm{g}\right)\end{array}$ & Pore Size (Å) & $\begin{array}{l}\text { Acid Sites } \\
\text { (mmol/g) }\end{array}$ & Ref. \\
\hline $\mathrm{Fe} / \mathrm{SiO}_{2}$ & 185 & 0.69 & 90 & 0.12 & [129] \\
\hline $\mathrm{Zn} / \mathrm{SiO}_{2}$ & 193 & 0.77 & 90 & 0.18 & [129] \\
\hline $\mathrm{Al} / \mathrm{SiO}_{2}$ & 493 & 0.8 & 82 & - & [126] \\
\hline $\mathrm{Cu} / \mathrm{SiO}_{2}$ & 190 & 0.72 & 90 & 0.18 & [129] \\
\hline $\mathrm{Ni}_{2} \mathrm{P} / \mathrm{SiO}_{2}$ & 116 & 0.44 & - & - & [142] \\
\hline $\mathrm{Ni} / \mathrm{MgO}$ & $59-64$ & $0.57-0.61$ & $270-289$ & - & [137] \\
\hline $\mathrm{Ni} / \mathrm{CNT}$ & 139 & - & 176 & - & [143] \\
\hline Co/CNT & 147 & - & 198 & - & [143] \\
\hline $\mathrm{NiCo} / \mathrm{CNT}$ & $153-160$ & - & $204-216$ & - & [143] \\
\hline NiMoS & 120 & - & - & - & [144] \\
\hline CoMos & 133 & - & - & - & [144] \\
\hline Carbon nanofiber (CNF) & 97 & 0.29 & 141 & - & [145] \\
\hline $\mathrm{NiCo} / \mathrm{CNF}$ & 101 & 0.36 & 158 & - & {$[145]$} \\
\hline $\mathrm{TiO}_{2}$ & 14 & 0.11 & 83 & 0.06 & [146] \\
\hline $\mathrm{ZrO}_{2} / \mathrm{TiO}_{2}$ & $31-103$ & $0.23-0.26$ & $45-71$ & $0.14-0.49$ & [146] \\
\hline $\mathrm{CoMo} / \mathrm{TiO}_{2}$ & 91 & 0.18 & 79 & 0.38 & [141] \\
\hline $\mathrm{ZrO}_{2}$ & 97 & 0.26 & 62 & 0.47 & [146] \\
\hline $\mathrm{NiSi} / \mathrm{ZrO}_{2}$ & $169-209$ & $0.61-0.74$ & $143-144$ & - & [133] \\
\hline $\mathrm{NiCo} / \mathrm{ZrO}_{2}$ & 40 & - & - & 0.04 & [124] \\
\hline $\mathrm{Cu}-\mathrm{Mo}_{2} \mathrm{C}$ & 23 & 0.06 & 90 & - & {$[147]$} \\
\hline Raney Ni & 11 & 0.02 & 41 & - & [148] \\
\hline Dolomite & 10 & 0.29 & 32 & - & [149] \\
\hline $\mathrm{Ni} / \mathrm{CMK}-3$ & 985 & 0.75 & 34 & - & [150] \\
\hline $\mathrm{Ni}-\mathrm{Mo}_{2} \mathrm{C}-\mathrm{H}$ & 11 & 0.05 & 190 & - & [147] \\
\hline
\end{tabular}

\subsection{Catalyst Deactivation and Regeneration}

During the vegetable oil upgrading to hydrocarbon biofuel, deactivation of catalysts is a significant factor for the catalytic performance and commercial economic consideration [151]. During the catalytic cracking process, many side reactions could cause the formation of carbonaceous material known as coke. Coke formation is a major factor in causing the catalyst deactivation. The coke can deposit on the external surface and/or internal pores of catalysts. The coke deposition over the catalyst active sites could affect the catalyst activity; and the coke deposition inside the catalyst pore structures affects the catalyst selectivity. Physical properties of catalysts including pore size, pore shape and crystallite size could strongly influence coke formation [73]. Other possible reasons for the catalyst deactivation include active metal leaching, and structural changes of catalyst components due to sintering and poisoning [151-153]. During the upgrading of bio-oil, the catalyst deactivation results from the coke due to the transformation of bio-oil oxygenates [19]. The mechanism of catalyst deactivation needs to be further understood.

Regeneration of used catalysts is one of the promising pathways to eliminate the cause of catalyst deactivation [151]. Table 11 shows some common catalyst regeneration methods. Used catalysts could be calcined in a furnace or reactor in air at high temperatures $\left(500-600{ }^{\circ} \mathrm{C}\right)$ for regeneration. Some researchers used acetone to wash the used catalysts prior to calcination, which may help remove some impurities (e.g., oil) deposited on the used catalysts. The continued regeneration (up to fifth regeneration) of the HZSM-5 zeolite gradually reduced the catalyst activity in converting bio-oil to an aromatic product. The prolonged reaction-regeneration cycles may result in the disappearance of a large amount of acid sites on the catalyst $[9,26]$. Directly regenerating the used catalysts in the reactor with air might be an efficient pathway, resulting in no need to unload and then load the catalysts. The reaction-regeneration cycle (up to third regeneration) gradually reduced the catalyst activity due to the modification of the acidity and texture of the Zn/HZSM- 5 catalyst. The Brønsted acid sites and intensity of the $\mathrm{Zn} / \mathrm{HZSM}-5$ catalyst decreased with the increase of the reaction-regeneration cycle. During the catalyst regeneration process, a high air flow rate could facilitate the sufficient combustion of coke, thus improving the recovery of the deactivated Zn/HZSM-5 [79,152]. Josl et al. studied the regeneration of used zeolite catalysts at $300{ }^{\circ} \mathrm{C}$ using a hydrogen pressure of 15 bar in a fixed-bed reactor. The activity of the zeolite catalysts using a hydrogen treatment method could be completely restored under suitable conditions [154]. Oxidation is also a method for the catalyst 
regeneration through introducing $\mathrm{O}_{2}$ or $\mathrm{N}_{2} \mathrm{O} . \mathrm{N}_{2} \mathrm{O}$ was a more efficient reactivation reagent for the deactivated zeolite catalysts than $\mathrm{O}_{2}$. The oxidative treatment of used catalyst at high temperatures for regeneration may cause some issues including catalyst destruction, dealumination, and agglomeration of doped metals. These regeneration issues may reduce the catalyst lifetime, resulting in the increased total cost. Oxidation and reduction (with $\mathrm{H}_{2}$ ) of deactivated Ni-zeolite catalyst was a successful regeneration process since it decreased the surface area and total pore volume of the catalyst, but it increased the acidity and activity $[151,155]$. Most solid alkylation catalysts seriously deactivate after $3-5$ cycles of reaction-regeneration by oxidation regeneration. Petkovic and Ginosar investigated the effect of supercritical isobutane regeneration on the coke deposited on a USY zeolite catalyst and found that the supercritical isobutane regeneration was effective in recovering the surface area and micropore volume of catalysts. A totally deactivated catalyst is difficult to be completely regenerated, but a partially deactivated catalyst could be fully regenerated [156]. Steam treatment is another method for the catalyst regeneration. This is helpful to tune the acidities of zeolites. During the coke burning of the regeneration process, the introduction of steam may prevent temperature runaway. The steam-treated Ag/HZSM- 5 catalyst maintained its initial activity during four reaction-regeneration cycles [157]. During the process of bio-oil upgrading, used catalysts were usually regenerated using an oxidation treatment through controlling regeneration temperature, regeneration time, and oxygen concentration [19]. Catalyst regeneration may cause undesirable downtime in a large scale-up commercial process [71]. Catalysts with high activity, high durability and high renewable capability need to be developed.

Firstly, a suitable regeneration of used catalysts could help reduce the cost of biofuel production from vegetable oil upgrading. Secondly, the vegetable oil feedstock may comprise a high cost due to expensive harvesting/extracting and competition with food resources. In recent years, various vegetable oils including food vegetable oil and non-food vegetable oil were studied. However, utilizing non-food vegetable oil sources such as camelina oil and waste vegetable oil should receive increased focus in the future in order to reduce the cost and reduce competition with food sources. In addition, a reasonable distribution of the vegetable oil feedstock should be designed to reduce the cost. Thirdly, developing high activity catalysts, optimizing the oil upgrading technologies, and improving the reactor system stability are significant for the cost reduction. Recently, more researches on the catalyst application from waste materials (e.g., red mud) have been reported. The utilization of waste for catalyst use could not only benefit the environment, but also reduce the biofuel production cost. The catalysts should be modified for the maximum effectiveness in the upgrading process with a high space velocity during a scale-up application. Various reactors including fixed-bed reactor, batch reactor, microactivity test reactor, and glass vessel have been studied at a lab-scale. However, in conventional petroleum refineries, most of the continuous biofuel production uses the concept of fluidized-bed reactor $[67,90,109,158-160]$. Recently, the scale-up of vegetable oil/bio-oil upgrading still needs more research targeted towards cheaper feedstock development, high activity catalysts, cost effective processing technology, and stable reactor system.

Table 11. The common catalyst regeneration methods.

\begin{tabular}{|c|c|c|c|}
\hline Catalyst & Treatment & Conditions & Ref. \\
\hline $\begin{array}{l}\text { HZSM- } 5 \text {, zeolite } \beta \text {, and } \\
\text { USY zeolite }\end{array}$ & Calcination & Calcined in a furnace at $600^{\circ} \mathrm{C}$ for $1-2 \mathrm{~h}$ & [74] \\
\hline Nanocrystalline zeolites & Calcination & $\begin{array}{l}\text { Washed with acetone and dried in oven at } 200^{\circ} \mathrm{C} \text {; calcined in a furnace at } \\
\qquad 550^{\circ} \mathrm{C} \text { for } 2 \mathrm{~h}\end{array}$ & [9] \\
\hline Zn/Na-ZSM-5 & Calcination & Calcined in a furnace in air at $575{ }^{\circ} \mathrm{C}$ until coke was removed & [32] \\
\hline HZSM-5 & Calcination & Washed with acetone and dried, heated in a furnace in air at $500{ }^{\circ} \mathrm{C}$ for $12 \mathrm{~h}$ & [26] \\
\hline Equilibrium catalyst & Calcination & Combusted in a fluidized bed reactor in air at $600{ }^{\circ} \mathrm{C}$ for $3 \mathrm{~h}$ & [79] \\
\hline Zn/HZSM-5 & Calcination & Heated in a fixed-bed reactor in air at $550^{\circ} \mathrm{C}$ for $4 \mathrm{~h}$ & [152] \\
\hline Zeolite & Hydrogen treatment & $\mathrm{H}_{2}(40 \mathrm{~mL} / \mathrm{min}), 300^{\circ} \mathrm{C}, 218 \mathrm{psi}, 7.25 \mathrm{~h}$ (total regeneration duration) & [154] \\
\hline
\end{tabular}


Table 11. Cont.

\begin{tabular}{|c|c|c|c|}
\hline Catalyst & Treatment & Conditions & Ref. \\
\hline $\mathrm{Ni} / \mathrm{ZA}$ (natural zeolite) & Oxidation & $\begin{array}{l}\text { Oxidized at } 400{ }^{\circ} \mathrm{C} \text { with } \mathrm{O}_{2}(10 \mathrm{~mL} / \mathrm{min}) \text { for } 4 \mathrm{~h} \text {, then reduced at } 400{ }^{\circ} \mathrm{C} \\
\text { with } \mathrm{H}_{2}(10 \mathrm{~mL} / \mathrm{min}) \text { for } 2 \mathrm{~h}\end{array}$ & {$[151]$} \\
\hline ZSM-5 zeolite & Oxidation & $425^{\circ} \mathrm{C}, 2.0 \mathrm{~mol} \% \mathrm{~N}_{2} \mathrm{O}$ in $\mathrm{He}$, fixed-bed flow reactor & {$[155]$} \\
\hline USY zeolite & Supercritical isobutane & $180^{\circ} \mathrm{C}, 1595 \mathrm{psi}, 1 \mathrm{~h}$ & {$[156]$} \\
\hline
\end{tabular}

\section{Conclusions and Future Prospects}

Vegetable oils, especially non-food vegetable oils, have great potential for conversion to hydrocarbon biofuel for transportation fuel use as improved climate factors. Catalytic cracking and hydroprocessing are two promising pathways to upgrade vegetable oil to hydrocarbon biofuel. In addition, the vegetable oil upgrading technologies could be applied for bio-oil upgrading. The vegetable oil upgrading to hydrocarbon biofuel is affected by several factors including the feedstock supply, fatty acid composition of vegetable oil, upgrading reaction temperature, pressure, catalyst activity/selectivity, etc. Compared to bio-oil with poor properties, upgrading vegetable oil seems to be the initial technology step towards high yield of hydrocarbon biofuel. Zeolite based catalysts and alumina based catalysts are usually used for both vegetable oil upgrading and bio-oil upgrading. The hydrocarbon biofuel produced mainly contains hydrocarbons and oxygenates, indicating a posttreatment such as distillation could be utilized for refining the hydrocarbon biofuel to meet the requirement of transportation fuel.

Catalyst deactivation is the main challenge for vegetable oil and bio-oil upgrading, but various regeneration methods (e.g., oxidation) could be used to recycle the catalysts. For the future, more advanced and economic catalysts with longer lifetime and higher activity need to be developed for eliminating the catalyst deactivation. In addition, the mechanism/kinetics of catalyst deactivation, catalyst regeneration, and oil upgrading needs to be understood. More non-food vegetable oilseeds with suitable properties could be explored for improving the hydrocarbon biofuel yield and quality. The byproduct obtained during the vegetable oil upgrading process (e.g., non-condensable gas and liquid oxygenates) should be recycled to improve the production economics. Finally, economic evaluation and scale-up of vegetable oil upgrading should be investigated.

Acknowledgments: This study was supported by USDA NIFA and N.C. Sun Grant Initiative. All support is gratefully acknowledged. However, only the authors are responsible for the opinions expressed in this paper and for any possible errors.

Author Contributions: Xianhui Zhao wrote the paper; Lin Wei proposed the review topics and partially wrote the introduction; and Shouyun Cheng and James Julson revised and proofread the paper.

Conflicts of Interest: The authors declare no conflict of interest.

\section{References}

1. Ahmad, M.; Farhana, R.; Raman, A.A.A.; Bhargava, S.K. Synthesis and activity evaluation of heterometallic nano oxides integrated ZSM-5 catalysts for palm oil cracking to produce biogasoline. Energy Convers. Manag. 2016, 119, 352-360. [CrossRef]

2. Huang, Y.; Wei, L.; Zhao, X.; Julson, J.; Qiu, C.; Dharmarajan, S.; Kiratu, J.; Raynie, D.; Dubey, A.; Qiao, Q. Biofuel production using $\mathrm{Pd} / \mathrm{Zn}$ synergistically catalyzed hydrodeoxygenation applied at bio oil extracted in biomass pyrolysis process. Int. J. Energy Res. 2016, 40, 1724-1730. [CrossRef]

3. Arapatsakos, C.; Karkanis, A.; Christoforidis, D.; Moschou, M.; Pantokratoras, I. Cotton oil and sunflower oil fuel mixtures. Adv. Petrol. Explor. Dev. 2011, 2, 47-51.

4. Helgeson, D.L.; Schaffner, L.W. Economics of sunflower oil as an extender or substitute for diesel fuel. N. D. Farm Res. 1982, 39, 21-24. 
5. Wei, L.; Gao, Y.; Qu, W.; Zhao, X.; Cheng, S. Torrefaction of raw and blended corn stover, switchgrass, and prairie grass. Trans. ASABE 2016, 59, 717-726.

6. Lee, H.; Kim, Y.-M.; Lee, I.-G.; Jeon, J.-K.; Jung, S.-C.; Chung, J.D.; Choi, W.G.; Park, Y.-K. Recent advances in the catalytic hydrodeoxygenation of bio-oil. Korean J. Chem. Eng. 2016, 33, 3299-3315. [CrossRef]

7. Yigezu, Z.D.; Muthukumar, K. Catalytic cracking of vegetable oil with metal oxides for biofuel production. Energy Convers. Manag. 2014, 84, 326-333. [CrossRef]

8. Al-Sabawi, M.; Chen, J.; Ng, S. Fluid catalytic cracking of biomass-derived oils and their blends with petroleum feedstocks: A review. Energy Fuels 2012, 26, 5355-5372. [CrossRef]

9. Taufiqurrahmi, N.; Mohamed, A.R.; Bhatia, S. Nanocrystalline zeolite beta and zeolite Y as catalysts in used palm oil cracking for the production of biofuel. J. Nanopart. Res. 2011, 13, 3177-3189. [CrossRef]

10. Domínguez-Barroso, M.V.; Herrera, C.; Larrubia, M.A.; Alemany, L.J. Diesel oil-like hydrocarbon production from vegetable oil in a single process over Pt-Ni/ $\mathrm{Al}_{2} \mathrm{O}_{3}$ and $\mathrm{Pd} / \mathrm{C}$ combined catalysts. Fuel Process. Technol. 2016, 148, 110-116. [CrossRef]

11. Kinder, J.D.; Rahmes, T. Evaluation of bio-derived synthetic paraffinic kerosene (bio-spk). Sustain. Biofuels Res. Technol. Progr. 2009, 1-10.

12. Knothe, G.; Dunn, R.O.; Bagby, M.O. Biodiesel: The use of vegetable oils and their derivatives as alternative diesel fuels. ACS Symp. Ser. 1997, 666, 172-208.

13. Nelson, R.J.; Kephart, K.D. Feedstock development in the north central region for green diesel and jet fuels. Brookings, SD: Sun Grant Initiative-North Central Center South Dakota State University. 2011, 1-12. Available online: http:/ / ncsungrant.sdstate.org/upload/North-Central-Region-Oilseed-White-Paper060811-2.pdf. (accessed 18 June 2012).

14. Liu, G.; Yan, B.; Chen, G. Technical review on jet fuel production. Renew. Sustain. Energy Rev. 2013, 25, 59-70. [CrossRef]

15. Zhao, X.; Wei, L.; Julson, J.; Huang, Y. Investigated cold press oil extraction from non-edible oilseeds for future bio-jet fuels production. J. Sustain. Bioenergy Syst. 2014, 04, 199-214. [CrossRef]

16. Zhao, X.; Wei, L.; Julson, J. First stage of bio-jet fuel production: Non-food sunflower oil extraction using cold press method. AIMS Energy 2014, 2, 193-209. [CrossRef]

17. Zhao, X.; Wei, L.; Julson, J.; Qiao, Q.; Dubey, A.; Anderson, G. Catalytic cracking of non-edible sunflower oil over ZSM-5 for hydrocarbon bio-jet fuel. New Biotechnol. 2015, 32, 300-312. [CrossRef] [PubMed]

18. Sieverding, H.L.; Zhao, X.; Wei, L.; Stone, J.J. Life-cycle assessment of oilseeds for biojet production using localized cold-press extraction. J. Environ. Qual. 2016, 45, 967-976. [CrossRef] [PubMed]

19. Cheng, S.; Wei, L.; Zhao, X.; Julson, J. Application, deactivation, and regeneration of heterogeneous catalysts in bio-oil upgrading. Catalysts 2016, 6, 195. [CrossRef]

20. Zhao, X.; Wei, L.; Julson, J.; Gu, Z.; Cao, Y. Catalytic cracking of inedible camelina oils to hydrocarbon fuels over bifunctional Zn/ZSM-5 catalysts. Korean J. Chem. Eng. 2015, 32, 1528-1541. [CrossRef]

21. Zhao, X.; Wei, L.; Cheng, S.; Huang, Y.; Yu, Y.; Julson, J. Catalytic cracking of camelina oil for hydrocarbon biofuel over ZSM-5-Zn catalyst. Fuel Process. Technol. 2015, 139, 117-126. [CrossRef]

22. Zarchin, R.; Rabaev, M.; Vidruk-Nehemya, R.; Landau, M.V.; Herskowitz, M. Hydroprocessing of soybean oil on nickel-phosphide supported catalysts. Fuel 2015, 139, 684-691. [CrossRef]

23. Sarajlija, H.; Čukelj, N.; Novotni, D.; Mršić, G.; Brnčić, M.; Ćurić, D. Preparation of flaxseed for lignin determination by gas chromatography-mass spectrometry method. Czech J. Food Sci. 2012, 30, 45-52.

24. Hemighaus, G.; Boval, T.; Bosley, C.; Organ, R.; Lind, J.; Brouette, R.; Thompson, T.; Lynch, J.; Jones, J. Alternative jet fuels. Chevron 2006, 1-13.

25. Ishihara, A.; Kawaraya, D.; Sonthisawate, T.; Kimura, K.; Hashimoto, T.; Nasu, H. Catalytic cracking of soybean oil by hierarchical zeolite containing mesoporous silica-aluminas using a curie point pyrolyzer. J. Mol. Catal. A Chem. 2015, 396, 310-318. [CrossRef]

26. Vitolo, S.; Bresci, B.; Seggiani, M.; Gallo, M.G. Catalytic upgrading of pyrolytic oils over HZSM-5 zeolite: Behaviour of the catalyst when used in repeated upgrading-regenerating cycles. Fuel 2001, 80, 17-26. [CrossRef]

27. Fan, K.; Liu, J.; Yang, X.; Rong, L. Hydrocracking of jatropha oil over Ni-H3PW12O40/nano-hydroxyapatite catalyst. Int. J. Hydrog. Energy 2014, 39, 3690-3697. [CrossRef]

28. Krar, M.; Kovacs, S.; Kallo, D.; Hancsok, J. Fuel purpose hydrotreating of sunflower oil on $\mathrm{CoMo} / \mathrm{Al}_{2} \mathrm{O}_{3}$ catalyst. Bioresour. Technol. 2010, 101, 9287-9293. [CrossRef] [PubMed] 
29. Srifa, A.; Faungnawakij, K.; Itthibenchapong, V.; Viriya-Empikul, N.; Charinpanitkul, T.; Assabumrungrat, S. Production of bio-hydrogenated diesel by catalytic hydrotreating of palm oil over $\mathrm{NiMoS}_{2} /$ gamma- $\mathrm{Al}_{2} \mathrm{O}_{3}$ catalyst. Bioresour. Technol. 2014, 158, 81-90. [CrossRef] [PubMed]

30. Huang, Y.; Wei, L.; Zhao, X.; Cheng, S.; Julson, J.; Cao, Y.; Gu, Z. Upgrading pine sawdust pyrolysis oil to green biofuels by hdo over zinc-assisted pd/c catalyst. Energy Convers. Manag. 2016, 115, 8-16. [CrossRef]

31. Zhao, X.; Wei, L.; Cheng, S.; Kadis, E.; Cao, Y.; Boakye, E.; Gu, Z.; Julson, J. Hydroprocessing of carinata oil for hydrocarbon biofuel over Mo-Zn/ $/ \mathrm{Al}_{2} \mathrm{O}_{3}$. Appl. Catal. B Environ. 2016, 196, 41-49. [CrossRef]

32. Zhao, X.; Wei, L.; Cheng, S.; Cao, Y.; Julson, J.; Gu, Z. Catalytic cracking of carinata oil for hydrocarbon biofuel over fresh and regenerated Zn/Na-ZSM-5. Appl. Catal. A Gen. 2015, 507, 44-55. [CrossRef]

33. Moser, B.R. Camelina (Camelina sativa L.) oil as a biofuels feedstock: Golden opportunity or false hope? Lipid Technol. 2010, 22, 270-273. [CrossRef]

34. Zhao, X.; Wei, L.; Julson, J. Effects of cold press operating conditions on vegetable oil fatty acid profiles. Int. J. Green Energy 2016, 13, 990-999. [CrossRef]

35. Popa, V.-M.; Gruia, A.; Raba, D.-N.; Dumbrava, D.; Moldovan, C.; Bordean, D.; Mateescu, C. Fatty acids composition and oil characteristics of linseed (Linum usitatissimum L.) from romania. J. Agroaliment. Process. Technol. 2012, 18, 136-140.

36. Liu, Y.; Sotelo-Boyás, R.; Murata, K.; Minowa, T.; Sakanishi, K. Hydrotreatment of vegetable oils to produce bio-hydrogenated diesel and liquefied petroleum gas fuel over catalysts containing sulfided Ni-Mo and solid acids. Energy Fuels 2011, 25, 4675-4685. [CrossRef]

37. Veriansyah, B.; Han, J.Y.; Kim, S.K.; Hong, S.-A.; Kim, Y.J.; Lim, J.S.; Shu, Y.-W.; Oh, S.-G.; Kim, J. Production of renewable diesel by hydroprocessing of soybean oil: Effect of catalysts. Fuel 2012, 94, 578-585. [CrossRef]

38. Sarin, R.; Sharma, M.; Khan, A.A. Terminalia belerica roxb. Seed oil: A potential biodiesel resource. Bioresour. Technol. 2010, 101, 1380-1384. [CrossRef] [PubMed]

39. Lima, D.G.; Soares, V.C.D.; Ribeiro, E.B.; Carvalho, D.A.; Cardoso, É.C.V.; Rassi, F.C.; Mundim, K.C.; Rubim, J.C.; Suarez, P.A.Z. Diesel-like fuel obtained by pyrolysis of vegetable oils. J. Anal. Appl. Pyrolysis 2004, 71, 987-996. [CrossRef]

40. Oliveira, L.E.; Da Silva, M.L.C.P. Comparative study of calorific value of rapeseed, soybean, jatropha curcas and crambe biodiesel. In Proceedings of the International Conference on Renewable Energies and Power Quality (ICREPQ'13), Bilbao, Spain, 20-22 March 2013; pp. 20-22.

41. Chakraborty, M.; Baruah, D.C.; Konwer, D. Investigation of terminalia (terminalia belerica robx.) seed oil as prospective biodiesel source for north-east india. Fuel Process. Technol. 2009, 90, 1435-1441. [CrossRef]

42. Bokhari, A.; Chuah, L.F.; Yusup, S.; Klemes, J.J.; Kamil, R.N. Optimisation on pretreatment of rubber seed (hevea brasiliensis) oil via esterification reaction in a hydrodynamic cavitation reactor. Bioresour. Technol. 2016, 199, 414-422. [CrossRef] [PubMed]

43. Wang, Z.; Yu, S. Production of liquid hydrocarbon fuel from catalytic cracking of rubber seed oil using new mesoporous molecular sieves. ACS Sustain. Chem. Eng. 2016, 4, 5594-5599. [CrossRef]

44. Bokhari, A.; Chuah, L.F.; Yusup, S.; Klemeš, J.J.; Akbar, M.M.; Kamil, R.N.M. Cleaner production of rubber seed oil methyl ester using a hydrodynamic cavitation: Optimisation and parametric study. J. Clean. Prod. 2016, 136, 31-41. [CrossRef]

45. Heikal, E.K.; Khalil, S.A.; Abdou, I.K. Jatropha bio-diesel production technologies. Int. J. Biosci. Biochem. Bioinform. 2013, 288-292. [CrossRef]

46. Olutoye, M.A.; Hameed, B.H. Kinetics and deactivation of a dual-site heterogeneous oxide catalyst during the transesterification of crude jatropha oil with methanol. J. Taibah Univ. Sci. 2016, 10, 685-699. [CrossRef]

47. Da Mota, S.A.P.; Mancio, A.A.; Lhamas, D.E.L.; de Abreu, D.H.; da Silva, M.S.; dos Santos, W.G.; de Castro, D.A.R.; de Oliveira, R.M.; Araújo, M.E.; Borges, L.E.P.; et al. Production of green diesel by thermal catalytic cracking of crude palm oil (elaeis guineensis jacq) in a pilot plant. J. Anal. Appl. Pyrolysis 2014, 110, 1-11. [CrossRef]

48. Almeida, S.C.A.D.; Belchior, C.R.; Nascimento, M.V.G.; Vieira, L.D.S.R.; Fleury, G. Performance of a diesel generator fuelled with palm oil. Fuel 2002, 81, 2097-2102. [CrossRef]

49. Syamsuddin, Y.; Murat, M.N.; Hameed, B.H. Synthesis of fatty acid methyl ester from the transesterification of high- and low-acid-content crude palm oil (Elaeis guineensis) and karanj oil (Pongamia pinnata) over a calcium-lanthanum-aluminum mixed-oxides catalyst. Bioresour. Technol. 2016, 214, 248-252. [CrossRef] [PubMed] 
50. Lovás, P.; Hudec, P.; Hadvinová, M.; Ház, A. Conversion of rapeseed oil via catalytic cracking: Effect of the ZSM-5 catalyst on the deoxygenation process. Fuel Process. Technol. 2015, 134, 223-230. [CrossRef]

51. Doronin, V.P.; Potapenko, O.V.; Lipin, P.V.; Sorokina, T.P. Catalytic cracking of vegetable oils and vacuum gas oil. Fuel 2013, 106, 757-765. [CrossRef]

52. Mihaela, P.; Josef, R.; Monica, N.; Rudolf, Z. Perspectives of safflower oil as biodiesel source for south eastern europe (comparative study: Safflower, soybean and rapeseed). Fuel 2013, 111, 114-119. [CrossRef]

53. Akhtar, N.; Adnan, Q.; Ahmad, M.; Mehmood, A.; Farzana, K. Rheological studies and characterization of different oils. J. Chem. Soc. Pak. 2009, 31, 201-206.

54. Saydut, A.; Duz, M.Z.; Kaya, C.; Kafadar, A.B.; Hamamci, C. Transesterified sesame (Sesamum indicum L.) seed oil as a biodiesel fuel. Bioresour. Technol. 2008, 99, 6656-6660. [CrossRef] [PubMed]

55. Fassinou, W.F.; Sako, A.; Fofana, A.; Koua, K.B.; Toure, S. Fatty acids composition as a means to estimate the high heating value (HHV) of vegetable oils and biodiesel fuels. Energy 2010, 35, 4949-4954. [CrossRef]

56. Rashid, U.; Anwar, F.; Knothe, G. Evaluation of biodiesel obtained from cottonseed oil. Fuel Process. Technol. 2009, 90, 1157-1163. [CrossRef]

57. Yenumala, S.R.; Maity, S.K.; Shee, D. Hydrodeoxygenation of karanja oil over supported nickel catalysts: Influence of support and nickel loading. Catal. Sci. Technol. 2016, 6, 3156-3165. [CrossRef]

58. Rathore, V.; Tyagi, S.; Newalkar, B.; Badoni, R.P. Jatropha and karanja oil derived dmc-biodiesel synthesis: A kinetics study. Fuel 2015, 140, 597-608. [CrossRef]

59. Srivastava, P.K.; Verma, M. Methyl ester of karanja oil as an alternative renewable source energy. Fuel 2008, 87, 1673-1677. [CrossRef]

60. Jham, G.N.; Moser, B.R.; Shah, S.N.; Holser, R.A.; Dhingra, O.D.; Vaughn, S.F.; Berhow, M.A.; Winkler-Moser, J.K.; Isbell, T.A.; Holloway, R.K.; et al. Wild brazilian mustard (Brassica juncea L.) seed oil methyl esters as biodiesel fuel. J. Am. Oil Chem. Soc. 2009, 86, 917-926. [CrossRef]

61. Boro, J.; Thakur, A.J.; Deka, D. Solid oxide derived from waste shells of turbonilla striatula as a renewable catalyst for biodiesel production. Fuel Process. Technol. 2011, 92, 2061-2067. [CrossRef]

62. Fadhil, A.B.; Abdulahad, W.S. Transesterification of mustard (Brassica nigra) seed oil with ethanol: Purification of the crude ethyl ester with activated carbon produced from de-oiled cake. Energy Convers. Manag. 2014, 77, 495-503. [CrossRef]

63. Hileman, J.I.; Ortiz, D.S.; Bartis, J.T.; Wong, H.M.; Donohoo, P.E.; Weiss, M.A.; Waitz, I.A. Near-Term Feasibility of Alternative Jet Fuels; RAND Corporation and Massachusetts Institute of Technology: Santa Monica, CA, USA, 2009.

64. Wang, H.; Farooqi, H.; Chen, J. Co-hydrotreating light cycle oil-canola oil blends. Front. Chem. Sci. Eng. 2016, 9, 64-76. [CrossRef]

65. Romero, M.J.; Pizzi, A.; Toscano, G.; Busca, G.; Bosio, B.; Arato, E. Deoxygenation of waste cooking oil and non-edible oil for the production of liquid hydrocarbon biofuels. Waste Manag. 2016, 47, 62-68. [CrossRef] [PubMed]

66. Demirbas, A. Studies on cottonseed oil biodiesel prepared in non-catalytic scf conditions. Bioresour. Technol. 2008, 99, 1125-1130. [CrossRef] [PubMed]

67. Kandaramath Hari, T.; Yaakob, Z.; Binitha, N.N. Aviation biofuel from renewable resources: Routes, opportunities and challenges. Renew. Sustain. Energy Rev. 2015, 42, 1234-1244. [CrossRef]

68. Kubátová, A.; Št'ávová, J.; Seames, W.S.; Luo, Y.; Sadrameli, S.M.; Linnen, M.J.; Baglayeva, G.V.; Smoliakova, I.P.; Kozliak, E.I. Triacylglyceride thermal cracking: Pathways to cyclic hydrocarbons. Energy Fuels 2012, 26, 672-685. [CrossRef]

69. Ramadhas, A.; Jayaraj, S.; Muraleedharan, C. Biodiesel production from high ffa rubber seed oil. Fuel 2005, 84, 335-340. [CrossRef]

70. Zhao, X.; Wei, L.; Cheng, S.; Julson, J.; Anderson, G.; Muthukumarappan, K.; Qiu, C. Development of hydrocarbon biofuel from sunflower seed and sunflower meat oils over ZSM-5. J. Renew. Sustain. Energy 2016, 8, 013109. [CrossRef]

71. Ruddy, D.A.; Schaidle, J.A.; Ferrell Iii, J.R.; Wang, J.; Moens, L.; Hensley, J.E. Recent advances in heterogeneous catalysts for bio-oil upgrading via "ex situ catalytic fast pyrolysis": Catalyst development through the study of model compounds. Green Chem. 2014, 16, 454-490. [CrossRef]

72. Patel, M.; Kumar, A. Production of renewable diesel through the hydroprocessing of lignocellulosic biomass-derived bio-oil: A review. Renew. Sustain. Energy Rev. 2016, 58, 1293-1307. [CrossRef] 
73. Asadieraghi, M.; Daud, W.M.A.W.; Abbas, H.F. Heterogeneous catalysts for advanced bio-fuel production through catalytic biomass pyrolysis vapor upgrading: A review. RSC Adv. 2015, 5, 22234-22255. [CrossRef]

74. Twaiq, F.A.; Zabidi, N.A.M.; Bhatia, S. Catalytic conversion of palm oil to hydrocarbons: Performance of various zeolite catalysts. Ind. Eng. Chem. Res. 1999, 38, 3230-3237. [CrossRef]

75. Saber, M.; Nakhshiniev, B.; Yoshikawa, K. A review of production and upgrading of algal bio-oil. Renew. Sustain. Energy Rev. 2016, 58, 918-930. [CrossRef]

76. Yigezu, Z.D.; Muthukumar, K. Biofuel production by catalytic cracking of sunflower oil using vanadium pentoxide. J. Anal. Appl. Pyrolysis 2015, 112, 341-347. [CrossRef]

77. Wu, X.; Jiang, P.; Jin, F.; Liu, J.; Zhang, Y.; Zhu, L.; Xia, T.; Shao, K.; Wang, T.; Li, Q. Production of jet fuel range biofuels by catalytic transformation of triglycerides based oils. Fuel 2017, 188, 205-211. [CrossRef]

78. Zhang, L.; Liu, R.; Yin, R.; Mei, Y. Upgrading of bio-oil from biomass fast pyrolysis in china: A review. Renew. Sustain. Energy Rev. 2013, 24, 66-72. [CrossRef]

79. Dupain, X.; Costa, D.J.; Schaverien, C.J.; Makkee, M.; Moulijn, J.A. Cracking of a rapeseed vegetable oil under realistic FCC conditions. Appl. Catal. B Environ. 2007, 72, 44-61. [CrossRef]

80. Twaiq, F.A.A.; Mohamad, A.R.; Bhatia, S. Performance of composite catalysts in palm oil cracking for the production of liquid fuels and chemicals. Fuel Process. Technol. 2004, 85, 1283-1300. [CrossRef]

81. Nam, L.T.H.; Vinh, T.Q.; Loan, N.T.T.; Tho, V.D.S.; Yang, X.-Y.; Su, B.-L. Preparation of bio-fuels by catalytic cracking reaction of vegetable oil sludge. Fuel 2011, 90, 1069-1075. [CrossRef]

82. Tamunaidu, P.; Bhatia, S. Catalytic cracking of palm oil for the production of biofuels: Optimization studies. Bioresour. Technol. 2007, 98, 3593-3601. [CrossRef] [PubMed]

83. Ooi, Y. Hydrothermal stability and catalytic activity of mesoporous aluminum-containing SBA-15. Catal. Commun. 2004, 5, 441-445. [CrossRef]

84. Toba, M.; Abe, Y.; Kuramochi, H.; Osako, M.; Mochizuki, T.; Yoshimura, Y. Hydrodeoxygenation of waste vegetable oil over sulfide catalysts. Catal. Today 2011, 164, 533-537. [CrossRef]

85. Kubička, D.; Kaluža, L. Deoxygenation of vegetable oils over sulfided Ni, Mo and NiMo catalysts. Appl. Catal. A Gen. 2010, 372, 199-208. [CrossRef]

86. Kubička, D.; Šimáček, P.; Žilková, N. Transformation of vegetable oils into hydrocarbons over mesoporousalumina-supported como catalysts. Top. Catal. 2008, 52, 161-168. [CrossRef]

87. Han, J.; Duan, J.; Chen, P.; Lou, H.; Zheng, X.; Hong, H. Nanostructured molybdenum carbides supported on carbon nanotubes as efficient catalysts for one-step hydrodeoxygenation and isomerization of vegetable oils. Green Chem. 2011, 13, 2561. [CrossRef]

88. Wang, C.; Tian, Z.; Wang, L.; Xu, R.; Liu, Q.; Qu, W.; Ma, H.; Wang, B. One-step hydrotreatment of vegetable oil to produce high quality diesel-range alkanes. ChemSusChem 2012, 5, 1974-1983. [CrossRef] [PubMed]

89. Satyarthi, J.K.; Chiranjeevi, T.; Gokak, D.T.; Viswanathan, P.S. An overview of catalytic conversion of vegetable oils/fats into middle distillates. Catal. Sci. Technol. 2013, 3, 70-80. [CrossRef]

90. Ong, Y.K.; Bhatia, S. The current status and perspectives of biofuel production via catalytic cracking of edible and non-edible oils. Energy 2010, 35, 111-119. [CrossRef]

91. Zacher, A.H.; Olarte, M.V.; Santosa, D.M.; Elliott, D.C.; Jones, S.B. A review and perspective of recent bio-oil hydrotreating research. Green Chem. 2014, 16, 491-515. [CrossRef]

92. Wang, H.; Yan, S.; Salley, S.O.; Ng, K.Y.S. Hydrocarbon fuels production from hydrocracking of soybean oil using transition metal carbides and nitrides supported on ZSM-5. Ind. Eng. Chem. Res. 2012, 51, 10066-10073. [CrossRef]

93. Bruce, E.D.; Frety, R.; Teixeira, C.M.; Barbosa, C.B.M.; Pacheco, J.G.A. Thermocatalytic cracking kinetics of myristic acid adsorbed on catalysts with different acidity. Catal. Today 2016. [CrossRef]

94. Li, T.; Cheng, J.; Huang, R.; Zhou, J.; Cen, K. Conversion pathways of palm oil into jet biofuel catalyzed by mesoporous zeolites. RSC Adv. 2016, 6, 103965-103972. [CrossRef]

95. Hemanandh, J.; Narayanan, K.V. Emission and performance analysis of hydrotreated refined sunflower oil as alternate fuel. Alex. Eng. J. 2015, 54, 389-393. [CrossRef]

96. Wang, W.-C.; Thapaliya, N.; Campos, A.; Stikeleather, L.F.; Roberts, W.L. Hydrocarbon fuels from vegetable oils via hydrolysis and thermo-catalytic decarboxylation. Fuel 2012, 95, 622-629. [CrossRef]

97. Zhao, X.; Wei, L.; Cheng, S.; Julson, J. Optimization of catalytic cracking process for upgrading camelina oil to hydrocarbon biofuel. Ind. Crops Prod. 2015, 77, 516-526. [CrossRef] 
98. Zhang, H.; Lin, H.; Wang, W.; Zheng, Y.; Hu, P. Hydroprocessing of waste cooking oil over a dispersed nano catalyst: Kinetics study and temperature effect. Appl. Catal. B Environ. 2014, 150-151, 238-248. [CrossRef]

99. Xiu, S.; Shahbazi, A. Bio-oil production and upgrading research: A review. Renew. Sustain. Energy Rev. 2012, 16, 4406-4414. [CrossRef]

100. Asikin-Mijan, N.; Lee, H.V.; Abdulkareem-Alsultan, G.; Afandi, A.; Taufiq-Yap, Y.H. Production of green diesel via cleaner catalytic deoxygenation of jatropha curcas oil. J. Clean. Prod. 2016. [CrossRef]

101. Cheng, S.; Wei, L.; Zhao, X.; Kadis, E.; Julson, J. Conversion of prairie cordgrass to hydrocarbon biofuel over Co-Mo/HZSM-5 using a two-stage reactor system. Energy Technol. 2016, 4, 706-713. [CrossRef]

102. Wang, H.; Yan, S.; Salley, S.O.; Simon Ng, K.Y. Support effects on hydrotreating of soybean oil over nimo carbide catalyst. Fuel 2013, 111, 81-87. [CrossRef]

103. Abbasov, V.; Mammadova, T.; Aliyeva, N.; Abbasov, M.; Movsumov, N.; Joshi, A.; Lvov, Y.; Abdullayev, E. Catalytic cracking of vegetable oils and vacuum gasoil with commercial high alumina zeolite and halloysite nanotubes for biofuel production. Fuel 2016, 181, 55-63. [CrossRef]

104. Huang, Y.; Wei, L.; Julson, J.; Gao, Y.; Zhao, X. Converting pine sawdust to advanced biofuel over HZSM-5 using a two-stage catalytic pyrolysis reactor. J. Anal. Appl. Pyrolysis 2015, 111, 148-155. [CrossRef]

105. Teixeira, C.M.; Fréty, R.; Barbosa, C.B.M.; Santos, M.R.; Bruce, E.D.; Pacheco, J.G.A. Mo influence on the kinetics of jatropha oil cracking over Mo/HZSM-5 catalysts. Catal. Today 2017, 279, 202-208. [CrossRef]

106. Cheng, S.; Wei, L.; Zhao, X.; Kadis, E.; Cao, Y.; Julson, J.; Gu, Z. Hydrodeoxygenation of prairie cordgrass bio-oil over ni based activated carbon synergistic catalysts combined with different metals. New Biotechnol. 2016, 33, 440-448. [CrossRef] [PubMed]

107. Hwang, K.-R.; Choi, I.-H.; Choi, H.-Y.; Han, J.-S.; Lee, K.-H.; Lee, J.-S. Bio fuel production from crude jatropha oil; addition effect of formic acid as an in-situ hydrogen source. Fuel 2016, 174, 107-113. [CrossRef]

108. Liu, Q.; Xin, R.; Li, C.; Xu, C.; Yang, J. Application of red mud as a basic catalyst for biodiesel production. J. Environ. Sci. 2013, 25, 823-829. [CrossRef]

109. Bennett, J.A.; Wilson, K.; Lee, A.F. Catalytic applications of waste derived materials. J. Mater. Chem. A 2016, 4, 3617-3637. [CrossRef]

110. Senthil, M.; Visagavel, K.; Saravanan, C.G.; Rajendran, K. Investigations of red mud as a catalyst in mahua oil biodiesel production and its engine performance. Fuel Process. Technol. 2016, 149, 7-14. [CrossRef]

111. Cheng, S.; Wei, L.; Zhao, X. Development of a bifunctional ni/hzsm-5 catalyst for converting prairie cordgrass to hydrocarbon biofuel. Energy Sources Part A Recover. Util. Environ. Eff. 2016, 38, 2433-2437. [CrossRef]

112. Wei, L.; Cheng, S.; Zhao, X.; Huang, Y.; Raynie, D.; Qiu, C.; Kiratu, J.; Yu, Y. Directly catalytic upgrading bio-oil vapor produced by prairie cordgrass pyrolysis over Ni/HZSM-5 using a two stage reactor. AIMS Energy 2015, 3, 227-240. [CrossRef]

113. Subsadsana, M.; Ruangviriyachai, C. Effect of niw modified HZSM-5 and hy zeolites on hydrocracking conversion of crude palm oil to liquid hydrocarbons. Orien. J. Chem. 2016, 32, 839-844. [CrossRef]

114. Li, L.; Ding, Z.; Li, K.; Xu, J.; Liu, F.; Liu, S.; Yu, S.; Xie, C.; Ge, X. Liquid hydrocarbon fuels from catalytic cracking of waste cooking oils using ultrastable zeolite USY as catalyst. J. Anal. Appl. Pyrol. 2016, 117, 268-272. [CrossRef]

115. Liu, Q.; Zuo, H.; Wang, T.; Ma, L.; Zhang, Q. One-step hydrodeoxygenation of palm oil to isomerized hydrocarbon fuels over Ni supported on nano-sized SAPO-11 catalysts. Appl. Catal. A Gen. 2013, 468, 68-74. [CrossRef]

116. Srifa, A.; Faungnawakij, K.; Itthibenchapong, V.; Assabumrungrat, S. Roles of monometallic catalysts in hydrodeoxygenation of palm oil to green diesel. Chem. Eng. J. 2015, 278, 249-258. [CrossRef]

117. Natewong, P.; Murakami, Y.; Tani, H.; Asami, K. Effect of support material on MgO-based catalyst for production of new hydrocarbon bio-diesel. Am. Sci. Res. J. Eng. Technol. Sci. (ASRJETS) 2016, 22, 153-165.

118. Yasir, M.; Azizan, M.T.; Ramli, A.; Ameen, M. Hydroprocessing of crude jatropha oil using hierarchical structured TiO2 nanocatalysts. Procedia Eng. 2016, 148, 275-281. [CrossRef]

119. Ma, Z.; Wei, L.; Zhou, W.; Jia, L.; Hou, B.; Li, D.; Zhao, Y. Overview of catalyst application in petroleum refinery for biomass catalytic pyrolysis and bio-oil upgrading. RSC Adv. 2015, 5, 88287-88297. [CrossRef]

120. Lee, E.H.; Park, R.-S.; Kim, H.; Park, S.H.; Jung, S.-C.; Jeon, J.-K.; Kim, S.C.; Park, Y.-K. Hydrodeoxygenation of guaiacol over Pt loaded zeolitic materials. J. Ind. Eng. Chem. 2016, 37, 18-21. [CrossRef] 
121. Lee, H.W.; Jun, B.R.; Kim, H.; Kim, D.H.; Jeon, J.-K.; Park, S.H.; Ko, C.H.; Kim, T.-W.; Park, Y.-K. Catalytic hydrodeoxygenation of 2-methoxy phenol and dibenzofuran over Pt/mesoporous zeolites. Energy 2015, 81, 33-40. [CrossRef]

122. Wei, Y.; Lei, H.; Zhu, L.; Zhang, X.; Liu, Y.; Yadavalli, G.; Zhu, X.; Qian, M.; Yan, D. Hydrocarbon produced from upgrading rich phenolic compound bio-oil with low catalyst coking. Fuel 2016, 178, 77-84. [CrossRef]

123. Lee, H.; Kim, H.; Yu, M.J.; Ko, C.H.; Jeon, J.K.; Jae, J.; Park, S.H.; Jung, S.C.; Park, Y.K. Catalytic hydrodeoxygenation of bio-oil model compounds over pt/hy catalyst. Sci. Rep. 2016, 6, 28765. [CrossRef] [PubMed]

124. Huynh, T.M.; Armbruster, U.; Atia, H.; Bentrup, U.; Phan, B.M.Q.; Eckelt, R.; Nguyen, L.H.; Nguyen, D.A.; Martin, A. Upgrading of bio-oil and subsequent co-processing under fcc conditions for fuel production. React. Chem. Eng. 2016, 1, 239-251. [CrossRef]

125. Karnjanakom, S.; Guan, G.; Asep, B.; Hao, X.; Kongparakul, S.; Samart, C.; Abudula, A. Catalytic upgrading of bio-oil over $\mathrm{Cu} / \mathrm{MCM}-41$ and $\mathrm{Cu} / \mathrm{KIT}-6$ prepared by $\beta$-cyclodextrin-assisted coimpregnation method. J. Phys. Chem. C 2016, 120, 3396-3407. [CrossRef]

126. Jang, M.S.; Park, R.-S.; Lee, I.-G.; Kwak, J.M.; Park, Y.-K.; Ko, C.H. Catalytic upgrading of lignin derived bio-oil model compound using mesoporous solid catalysts. Res. Chem. Intermed. 2015, 42, 3-17. [CrossRef]

127. Gamliel, D.P.; Cho, H.J.; Fan, W.; Valla, J.A. On the effectiveness of tailored mesoporous mfi zeolites for biomass catalytic fast pyrolysis. Appl. Catal. A Gen. 2016, 522, 109-119. [CrossRef]

128. Foster, A.J.; Jae, J.; Cheng, Y.-T.; Huber, G.W.; Lobo, R.F. Optimizing the aromatic yield and distribution from catalytic fast pyrolysis of biomass over zsm-5. Appl. Catal. A Gen. 2012, 423-424, 154-161. [CrossRef]

129. Karnjanakom, S.; Guan, G.; Asep, B.; Du, X.; Hao, X.; Yang, J.; Samart, C.; Abudula, A. A green method to increase yield and quality of bio-oil: Ultrasonic pretreatment of biomass and catalytic upgrading of bio-oil over metal (Cu, Fe and/or Zn)/ $\gamma$-Al2O3. RSC Adv. 2015, 5, 83494-83503. [CrossRef]

130. Karnjanakom, S.; Bayu, A.; Hao, X.; Kongparakul, S.; Samart, C.; Abudula, A.; Guan, G. Selectively catalytic upgrading of bio-oil to aromatic hydrocarbons over zn, ce or Ni-doped mesoporous rod-like alumina catalysts. J. Mol. Catal. A Chem. 2016, 421, 235-244. [CrossRef]

131. Oh, S.; Hwang, H.; Choi, H.S.; Choi, J.W. The effects of noble metal catalysts on the bio-oil quality during the hydrodeoxygenative upgrading process. Fuel 2015, 153, 535-543. [CrossRef]

132. He, P.; Shan, W.; Xiao, Y.; Song, H. Performance of Zn/ZSM-5 for in situ catalytic upgrading of pyrolysis bio-oil by methane. Top. Catal. 2015, 59, 86-93. [CrossRef]

133. Zhang, X.; Chen, L.; Kong, W.; Wang, T.; Zhang, Q.; Long, J.; Xu, Y.; Ma, L. Upgrading of bio-oil to boiler fuel by catalytic hydrotreatment and esterification in an efficient process. Energy 2015, 84, 83-90. [CrossRef]

134. Zhang, X.; Wang, T.; Ma, L.; Zhang, Q.; Jiang, T. Hydrotreatment of bio-oil over Ni-based catalyst. Bioresour. Technol. 2013, 127, 306-311. [CrossRef] [PubMed]

135. Ibarra, Á.; Veloso, A.; Bilbao, J.; Arandes, J.M.; Castaño, P. Dual coke deactivation pathways during the catalytic cracking of raw bio-oil and vacuum gasoil in FCC conditions. Appl. Catal. B Environ. 2016, 182, 336-346. [CrossRef]

136. Widayatno, W.B.; Guan, G.; Rizkiana, J.; Yang, J.; Hao, X.; Tsutsumi, A.; Abudula, A. Upgrading of bio-oil from biomass pyrolysis over $\mathrm{Cu}$-modified $\beta$-zeolite catalyst with high selectivity and stability. Appl. Catal. $B$ Environ. 2016, 186, 166-172. [CrossRef]

137. Zhang, X.; Zhang, Q.; Wang, T.; Li, B.; Xu, Y.; Ma, L. Efficient upgrading process for production of low quality fuel from bio-oil. Fuel 2016, 179, 312-321. [CrossRef]

138. Manayil, J.C.; Inocencio, C.V.M.; Lee, A.F.; Wilson, K. Mesoporous sulfonic acid silicas for pyrolysis bio-oil upgrading via acetic acid esterification. Green Chem. 2016, 18, 1387-1394. [CrossRef]

139. Ly, H.V.; Im, K.; Go, Y.; Galiwango, E.; Kim, S.-S.; Kim, J.; Choi, J.H.; Woo, H.C. Spray pyrolysis synthesis of $\gamma-\mathrm{Al}_{2} \mathrm{O}_{3}$ supported metal and metal phosphide catalysts and their activity in the hydrodeoxygenation of a bio-oil model compound. Energy Convers. Manag. 2016, 127, 545-553. [CrossRef]

140. Saidi, M.; Rahimpour, H.R.; Rahzani, B.; Rostami, P.; Gates, B.C.; Rahimpour, M.R. Hydroprocessing of 4-methylanisole as a representative of lignin-derived bio-oils catalyzed by sulphided $\mathrm{CoMo} / \gamma-\mathrm{Al}_{2} \mathrm{O}_{3}$ : A semi-quantitative reaction network. Can. J. Chem. Eng. 2016, 94, 1524-1532. [CrossRef]

141. Goodwin, V.; Yoosuk, B.; Ratana, T.; Tungkamani, S. Hydrotreating of free fatty acid and bio-oil model compounds: Effect of catalyst support. Energy Procedia 2015, 79, 486-491. [CrossRef] 
142. Koike, N.; Hosokai, S.; Takagaki, A.; Nishimura, S.; Kikuchi, R.; Ebitani, K.; Suzuki, Y.; Oyama, S.T. Upgrading of pyrolysis bio-oil using nickel phosphide catalysts. J. Catal. 2016, 333, 115-126. [CrossRef]

143. Zhou, M.; Wang, Y.; Wang, Y.; Xiao, G. Catalytic conversion of guaiacol to alcohols for bio-oil upgrading. J. Energy Chem. 2015, 24, 425-431. [CrossRef]

144. Horáček, J.; Kubička, D. Bio-oil hydrotreating over conventional como \& nimo catalysts: The role of reaction conditions and additives. Fuel 2016. [CrossRef]

145. Remón, J.; Arauzo, J.; García, L.; Arcelus-Arrillaga, P.; Millan, M.; Suelves, I.; Pinilla, J.L. Bio-oil upgrading in supercritical water using ni-co catalysts supported on carbon nanofibres. Fuel Process. Technol. 2016, 154, 178-187. [CrossRef]

146. Liu, Y.; Li, Z.; Leahy, J.J.; Kwapinski, W. Catalytically upgrading bio-oil via esterification. Energy Fuels 2015, 29, 3691-3698. [CrossRef]

147. Choi, J.-S.; Zacher, A.H.; Wang, H.; Olarte, M.V.; Armstrong, B.L.; Meyer, H.M.; Soykal, I.I.; Schwartz, V. Molybdenum carbides, active andin situregenerable catalysts in hydroprocessing of fast pyrolysis bio-oil. Energy Fuels 2016, 30, 5016-5026. [CrossRef]

148. Xu, Y.; Long, J.; Liu, Q.; Li, Y.; Wang, C.; Zhang, Q.; Lv, W.; Zhang, X.; Qiu, S.; Wang, T.; et al. In situ hydrogenation of model compounds and raw bio-oil over raney ni catalyst. Energy Convers. Manag. 2015, 89, 188-196. [CrossRef]

149. Valle, B.; Aramburu, B.; Santiviago, C.; Bilbao, J.; Gayubo, A.G. Upgrading of bio-oil in a continuous process with dolomite catalyst. Energy Fuels 2014, 28, 6419-6428. [CrossRef]

150. Xu, Y.; Li, Y.; Wang, C.; Wang, C.; Ma, L.; Wang, T.; Zhang, X.; Zhang, Q. In-situ hydrogenation of model compounds and raw bio-oil over Ni/CMK-3 catalyst. Fuel Process. Technol. 2016. [CrossRef]

151. Khabib, I.; Kadarwati, S.; Wahyuni, S. Deactivation and regeneration of Ni/Za catalyst in hydrocracking of polypropylene. Indones. J. Chem. 2014, 14, 192-198. [CrossRef]

152. Zhang, G.; Zhang, X.; Bai, T.; Chen, T.; Fan, W. Coking kinetics and influence of reaction-regeneration on acidity, activity and deactivation of Zn/HZSM-5 catalyst during methanol aromatization. J. Energy Chem. 2015, 24, 108-118. [CrossRef]

153. Ginosar, D.M.; Thompson, D.N.; Burch, K.C. Recovery of alkylation activity in deactivated USY catalyst using supercritical fluids: A comparison of light hydrocarbons. Appl. Catal. A Gen. 2004, 262, 223-231. [CrossRef]

154. Josl, R. Regeneration of zeolite catalysts deactivated in isobutane/butene alkylation: An in situ ftir investigation at elevated $\mathrm{H} 2$ pressure. Catal. Commun. 2004, 5, 239-241. [CrossRef]

155. Ivanov, D.P.; Sobolev, V.I.; Panov, G.I. Deactivation by coking and regeneration of zeolite catalysts for benzene-to-phenol oxidation. Appl. Catal. A Gen. 2003, 241, 113-121. [CrossRef]

156. Petkovic, L.M.; Ginosar, D.M. The effect of supercritical isobutane regeneration on the nature of hydrocarbons deposited on a USY zeolite catalyst utilized for isobutane/butene alkylation. Appl. Catal. A Gen. 2004, 275, 235-245. [CrossRef]

157. Zhang, R.; Wang, Z. Catalytic cracking of 1-butene to propylene by ag modified hzsm-5. Chin. J. Chem. Eng. 2015, 23, 1131-1137. [CrossRef]

158. Farrauto, R.J.; Armor, J.N. Moving from discovery to real applications for your catalyst. Appl. Catal. A Gen. 2016, 527, 182-189. [CrossRef]

159. Mittelbach, M. Fuels from oils and fats: Recent developments and perspectives. Eur. J. Lipid Sci. Technol. 2015, 117, 1832-1846. [CrossRef]

160. Maity, S.K. Opportunities, recent trends and challenges of integrated biorefinery: Part i. Renew. Sustain. Energy Rev. 2015, 43, 1427-1445. [CrossRef]

(c) 2017 by the authors. Licensee MDPI, Basel, Switzerland. This article is an open access article distributed under the terms and conditions of the Creative Commons Attribution (CC BY) license (http:/ / creativecommons.org/licenses/by/4.0/). 